\title{
The seabed appearance of different coral bank provinces in the Porcupine Seabight, NE Atlantic: results from sidescan sonar and ROV seabed mapping
}

\author{
Veerle A. I. Huvenne ${ }^{1,2}$, Andreas Beyer ${ }^{3}$, Henk de Haas ${ }^{4}$, Karine Dekindt ${ }^{5}$, \\ Jean-Pierre Henriet ${ }^{1}$, Maxim Kozachenko ${ }^{6}$, Karine Olu-Le Roy ${ }^{5}$, \\ Andrew J. Wheeler ${ }^{6}$ and the TOBI/Pelagia 197 and CARACOLE cruise \\ participants
}

${ }^{\prime}$ Renard Centre of Marine Geology, Gent University, Krijgslaan 281, S8, B-9000 Gent, Belgium

${ }^{2}$ Present address: Challenger Division for Seafloor Processes, Southampton Oceanography Centre, Empress Dock, Southampton, SOl 4 3ZH, UK (vaih@soc.soton.ac.uk)

${ }^{3}$ Alfred Wegener Institute for Polar and Marine Research, Columbusstr., D-27568 Bremerhaven, Germany

${ }^{4}$ Koninklijk Nederlands Instituut voor Onderzoek der Zee (NIOZ), P.O. Box 59, NL-1790 AB Den Burg, Texel, The Netherlands

${ }^{5}$ IFREMER, Centre de Brest, BP 70, F-29280 Plouzané, France

${ }^{6}$ Department of Geology, Environmental Research Institute, University College Cork, Ireland

\begin{abstract}
Carbonate mounds, identified as deep-water coral banks, have been reported recently from three provinces in the Porcupine Seabight, SW of Ireland. As yet, the mechanisms behind their formation and development are only partly understood. This contribution discusses their seabed appearance and present-day sedimentary environment, based on a large-scale TOBI sidescan sonar mapping carried out in 2002, and on detailed ROV video records from specific sites within the three mound provinces, collected in 2001. The study of the presentday characteristics and variability of these mounds can help to understand their development history in the past.

The imagery clearly shows that the sedimentary environment in the Magellan and Hovland Mound provinces in the northern Porcupine Seabight is much quieter than in the current-swept Belgica Mound province on the eastern flank of the basin. In the latter area, for example, gravel lags and coarse sediments are found, together with patches of sorted sands, striations, barchan dunes and sediment waves. The difference in environment results in different mound appearances. The richest coral communities with the most abundant live coral occurrences are found in the Belgica
\end{abstract}

Freiwald A, Roberts JM (eds), 2005, Cold-water Corals and Ecosystems. Springer-Verlag Berlin Heidelberg, pp 535-569 
province, while for example on the Magellan Mounds only a few live coral colonies are left. The present-day situation of the coral banks in the Porcupine Seabight thus illustrates the influence of the interplay between current and sediment dynamics on coral growth and mound development.

Keywords. Deep-water corals, seabed facies mapping, sedimentary bedforms, Porcupine Seabight, ROV, sidescan sonar

\section{Introduction and background}

Over the last decennia, large mound structures were discovered along the NE Atlantic continental margin, W of Ireland (Hovland et al. 1994; Henriet et al. 1998; De Mol et al. 2002; Kenyon et al. 2003). In the Porcupine Seabight they occur in 3 provinces, indicated on the location map in Figure 1: the Magellan, Hovland and Belgica Mound provinces. Deep-water corals and coral fragments were encountered on the summits, flanks and in the upper metres of several of them, prompting De Mol et al. (2002) to classify these mounds as 'coral banks'. The main species found are Lophelia pertusa (Linné, 1758) and Madrepora oculata Linné, 1758 (Kenyon et al. 1998), but also other corals such as Desmophyllum cristagalli have been reported (Olu-Le Roy et al. 2002; H. Zibrowius and A. Freiwald pers. comm.). The occurrence of deep-water corals in this area is known since at least the historical cruise of the HMS Porcupine (Thomson 1873), and both Pratje (1924) and Le Danois (1948) incorporated the Porcupine Seabight in their early maps of the coral distribution along the European margin. But only when the offshore industry, moving into deeper waters, re-discovered the corals and mounds some decades ago, did scientific interest for these enigmatic structures rise again.

Major questions concerning the origin and formation controls of the coral banks have been posed. It has been suggested that they are caused and controlled by the seepage of hydrocarbons from depth (e.g., Hovland et al. 1994; Henriet et al. 1998, 2001), by the establishment of specific oceanographic conditions (e.g., Kenyon et al. 1998; De Mol et al. 2002) or by a combination of the two (Henriet et al. 2002). In order to gain more insight, the banks were studied with a variety of techniques, partly within the EU $5^{\text {th }}$ Framework projects GEOMOUND, ECOMOUND and ACES. 2D and 3D seismic data showed the geological context and embedding sediment packages (De Mol et al. 2002; Huvenne et al. 2003). Cores and video observations supplied local information of the seabed and the shallow subsurface on and around the mounds (Kenyon et al. 1998), and were recently complemented with ROV video observations acquired during the CARACOLE cruise on board of the R/V L'Atalante (Olu-Le Roy et al. 2002). A limited sidescan sonar survey carried out during the Training-Through-Research cruises 7 and 8 (Kenyon et al. 1998, 1999), together with a high-resolution sidescan sonar survey over part of the Belgica Mound province (Wheeler et al. 2000; Wheeler et al. 2005) illustrated the power of this technique in mapping the seabed characteristics. Partly based on these results, a large-scale $30 \mathrm{kHz}$ TOBI (Towed Ocean Bottom Instrument) sidescan sonar survey was planned and carried out in summer 2002 over the various mound provinces in order to map them in full, in a consistent manner. 


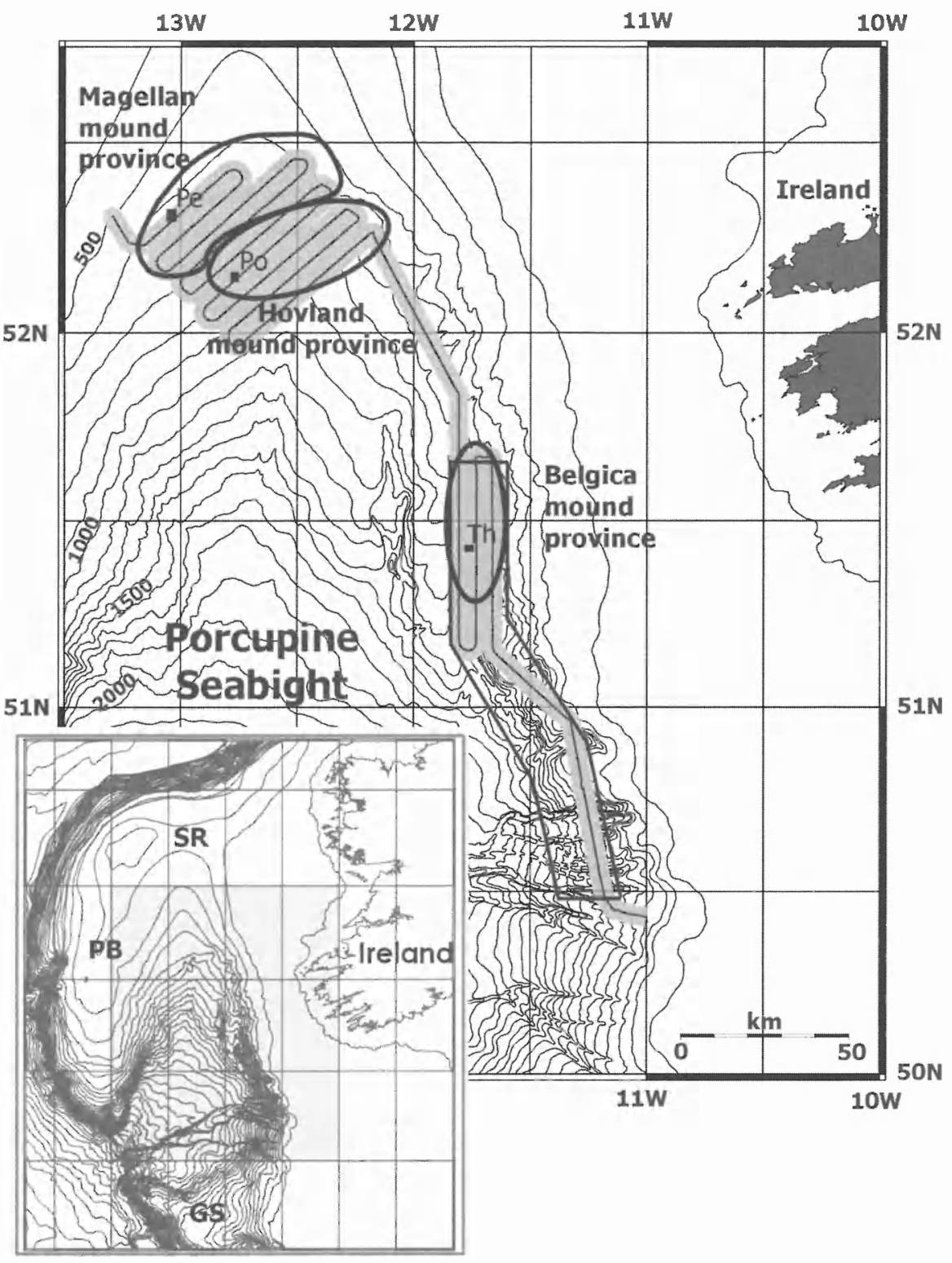

Fig. 1 Overview map of the Porcupine Seabight, its mound provinces and the data sets used in this study. The coverage of the 2002 TOBI sidescan sonar survey is indicated in grey; the locations of the 3 dive sites of the 2001 CARACOLE cruise ROV dives are marked with small black boxes (Pe: Mound Perseverance, dive 127; Po: Propeller Mound, dive 126; Th: Thérèse Mound, dives 123 to 125; see Table 1). The area delineated along the eastern flank of the Seabight was covered during the 2000 multibeam survey with the R/V Polarstern. The inset to the left situates the Seabight along the Irish continental margin, the coverage of the main map is marked with a grey box (PB: Porcupine Bank, SR: Slyne Ridge, GS: Goban Spur) 
This paper presents the results of the seabed mapping in the Porcupine Mound provinces. An accurate knowledge of the present morphology and characteristics of the different types of mounds in the area, together with the sedimentary processes affecting them, will help in the understanding of the past formation and development of the mounds. Furthermore, based on the ROV video footage collected during the CARACOLE cruise, together with the information from sidescan sonar mapping, one mound from each province is discussed in detail as an illustration of the specific conditions around mounds in that province.

\section{Setting}

\section{Geology}

The Porcupine Seabight forms an embayment in the continental margin, bound by the Porcupine Bank, the Slyne Ridge, the Irish shelf and the Goban Spur (Fig. 1). It overlies the Porcupine Basin, a deep sedimentary basin that formed as a failed rift during the opening of the North Atlantic Ocean. The major rifting phases occurred during the Permo-Triassic, Late Jurassic and Middle Cretaceous (Sinclair et al. 1994), and were followed by basin subsidence and sedimentation. Locally the Cretaceous and Tertiary sequences can be more than $9 \mathrm{~km}$ thick. The most recent sedimentation in the area consists mainly of (hemi) pelagic and locally reworked sediments which appear to become finer towards greater depth (Rice et al. 1991). At depths of ca. 500 to $1000 \mathrm{~m}$, where the mounds occur, the general succession in cores consists of an upper layer of Holocene, foraminiferal sands, representative of the interglacial sedimentary environment, overlying several metres of silty clays or marls with dropstones, deposited during the last glacial event (Swennen et al. 1998; De Mol 2002; Foubert 2002). On the eastern flank of the Porcupine Seabight, in the Belgica Mound area, Van Rooij et al. (2003) found seismic evidence for the existence of two types of sediment drift. An elongated and a confined drift of presumably Quaternary age occur in the sedimentary sequences within which also the mounds are embedded.

\section{Hydrography}

Water depths in the Porcupine Seabight range from less than $400 \mathrm{~m}$ in the north to more than $3000 \mathrm{~m}$ in the southwest, where the embayment opens onto the Porcupine Abyssal Plain (Fig. 1). The water mass structure in the Seabight was described by Rice et al. (1991), Mohn (2000) and White (2001), and consists of an upper layer of $750 \mathrm{~m}$ of Eastern North Atlantic Water (ENAW), overlying a core of Mediterranean Outflow Water (MOW), reaching down to ca. $1500 \mathrm{~m}$, marked by a salinity maximum and oxygen minimum. A fresher and more oxygen-rich layer of Labrador Sea Water is located between ca. 1500 and $1800 \mathrm{~m}$, and is underlain by Norwegian Sea Water. In general, a poleward (northward) boundary or slope current is described along the NE Atlantic continental margin (e.g., Huthnance et al. 1986; Kenyon 1986). The existence of a general northward flow along the slope in the Porcupine Seabight has indeed been confirmed by several sets of current 
measurements, e.g. as reported by Pingree and Le Cann $(1989,1990)$. White (2001) found a mean northward bottom current of $2-5 \mathrm{~cm} / \mathrm{s}$, however steered cyclonically by the topography in the north of the Porcupine Seabight. In that area currents appeared the weakest and most variable ones. In addition to these average residual currents, strong tidal influences were reported by Pingree and Le Cann (1989) from the eastern flank of the Seabight (both semi-diurnal and diurnal tides) and by Mohn et al. (2002) from the flanks of the Porcupine Bank (diurnal tide). Some of these tidal signals, for example on the eastern flank of the Seabight, appear to be caused by internal tides (Pingree and Le Cann 1989). Rice et al. (1990) mapped the zones where semi-diurnal internal tides could be created or enhanced, and part of these coincide with the Belgica Mound province.

\section{Mounds and corals}

In total 3 mound provinces were discovered in the Porcupine Seabight during the last decennia (De Mol et al. 2002; Fig. 1). The Hovland Mound province is located in the north, and was originally described by Hovland et al. (1994). The mounds are conical to elongated, ridge-like structures, reaching up to $150 \mathrm{~m}$ above the seabed. The Magellan Mound province is located just north and west of the Hovland province. A very large number of mainly smaller mounds have been found in this area, they are nowadays mostly buried under semi-parallel stratified sediments (Huvenne et al. 2003). Along the eastern flank of the Seabight lies the Belgica Mound province, comprising a set of mostly conical mounds, partly buried by sediments at their upslope flank (Henriet et al. 1998). Most of these mounds are still visible at the present-day seafloor, and they can reach a height of up to $100 \mathrm{~m}$ above the seabed. Some, however, are already buried. The main coral species found on the banks, Lophelia pertusa and Madrepora oculata, are known to prefer locations with enhanced current regimes (such as local elevations) and need a hard substrate for their initial settlement (e.g., rock, hardground, a dropstone or piece of coral; Freiwald 1998; Rogers 1999; Mortensen et al. 2001). Furthermore, they tend to live in waters of 4 to $12^{\circ} \mathrm{C}$, with a salinity varying between 34 and $37 \%$ and with a sufficient food supply.

\section{Material and methods}

The main data used for this study are TOBI sidescan sonar mosaics and ROV Victor 6000 video footage. The TOBI sidescan sonar data were recorded in July 2002, during a cruise of the R/V Pelagia in the Porcupine Seabight and Rockall Trough (de Haas et al. 2002). TOBI stands for Towed Ocean Bottom Instrument, a deep-towed vehicle developed at the Southampton Oceanography Centre (UK). The main instrument is a $30 \mathrm{kHz}$ sidescan sonar with a swath width of $2 \times 3000 \mathrm{~m}$. During the survey, the vehicle was towed at a constant speed of $2.5 \mathrm{kn}$ and was kept at a height of about 300 to $400 \mathrm{~m}$ above the seabed. The survey track plot is shown in Figure 1: ca. $2300 \mathrm{~km}^{2}$ of seafloor were mapped in the Hovland/Magellan area and $1000 \mathrm{~km}^{2}$ over the Belgica province. For data processing, the software package PRISM ('Processing Remotely sensed Imagery for Seafloor Mapping'; 
LeBas 2002) and the image processing software ERDAS were used, resulting in mosaics with a pixel resolution of $6 \times 6 \mathrm{~m}$. The data interpretation was carried out partly on paper, but mostly within the GIS software ArcView v3.2. Ground-truthing was based on existing data sets. In particular, core descriptions from various types of coring operations, carried out during different cruises were used (Swennen et al. 1998; De Mol et al. 1999; de Haas et al. 2000, 2002; Freiwald et al. 2000; Freiwald and Shipboard Party 2002; Van Rooij et al. 2001; De Mol 2002). Furthermore, the interpretation of video transects collected during the TTR7 cruise (Kenyon et al. 1998; De Bergé 2000), the $3.5 \mathrm{kHz}$ shipboard subbottom profiler records acquired during the sidescan survey and the ROV Victor 6000 video footage (see below) were also used for ground-truthing. Bathymetric information, kindly provided by the Geological Survey of Ireland (GSI Dublin) was used to aid in the interpretation of the sidescan imagery of the Hovland/Magellan area. Bathymetry data of the Belgica Mound province was collected during the $2000 \mathrm{R} / \mathrm{V}$ Polarstern cruise ANT XVII/4, using a Hydrosweep DS2 system. Processing of these data occurred at the Alfred-Wegener-Institute (Bremerhaven) and resulted in a digital terrain model of the area with horizontal resolution of $50 \times 50 \mathrm{~m}$.

Several dives of IFREMER's Remotely Operated Vehicle (ROV) Victor 6000 were carried out in the Porcupine Seabight during the 2001 CARACOLE cruise of the R/V L'Atalante (Olu-Le Roy et al. 2002). The specifications of the dives are given in Table 1 and the dive sites are indicated on Figure 1. The first dive on Thérèse Mound was used to acquire a high-resolution multibeam grid (Opderbecke and Pitout 2002; Hinsinger 2002). The other dives were targeted at video observations, together with the sampling of sediment and biota and the collection of digital photographs. Post-processing of the dive data was based on the software 'Adélie' (a set of ArcView-based routines developed at IFREMER for the analysis of ROV and submersible data) and included the correction of the navigation data and the

Table 1 Specifications of the CARACOLE ROV dives targeted towards different mounds in the Porcupine Seabight

\begin{tabular}{|l|c|c|c|c|c|}
\hline dive number & 123 & 124 & 125 & 126 & 127 \\
\hline location & $\begin{array}{c}\text { Thérèse } \\
\text { Mound }\end{array}$ & $\begin{array}{c}\text { Thérèse } \\
\text { Mound }\end{array}$ & $\begin{array}{c}\text { Thérèse } \\
\text { Mound }\end{array}$ & $\begin{array}{c}\text { Propeller } \\
\text { Mound }\end{array}$ & $\begin{array}{c}\text { Mound } \\
\text { Perseverance }\end{array}$ \\
\hline start latitude & $51^{\circ} 25.42^{\prime}$ & $51^{\circ} 25.88^{\prime}$ & $51^{\circ} 25.05^{\circ}$ & $52^{\circ} 13.94^{\prime}$ & $53^{\circ} 18.12^{\prime}$ \\
\hline start longitude & $-11^{\circ} 46.54^{\prime}$ & $-11^{\circ} 45.21^{\prime}$ & $-11^{\circ} 47.58^{\prime}$ & $-12^{\circ} 45.46^{\prime}$ & $-13^{\circ} 02.15^{\prime}$ \\
\hline min depth & $847 \mathrm{~m}$ & $807 \mathrm{~m}$ & $860 \mathrm{~m}$ & $670 \mathrm{~m}$ & $598 \mathrm{~m}$ \\
\hline $\begin{array}{l}\text { max depth } \\
\text { total time on } \\
\text { seabed }\end{array}$ & $1016 \mathrm{~m}$ & $1016 \mathrm{~m}$ & $961 \mathrm{~m}$ & $869 \mathrm{~m}$ & $671 \mathrm{~m}$ \\
\hline total length & $14 \mathrm{~h} 20$ & $14 \mathrm{~h} 43$ & $17 \mathrm{~h} 36$ & $12 \mathrm{~h} 04$ & $14 \mathrm{~h} 36$ \\
\hline main aim & $\begin{array}{c}\text { high-res. } \\
\text { multibeam } \\
\text { bathymetry \& } \\
\text { video survey }\end{array}$ & $\begin{array}{c}\text { sampling and } \\
\text { video } \\
\text { surveying }\end{array}$ & $\begin{array}{c}\text { sampling and } \\
\text { video } \\
\text { surveying }\end{array}$ & $\begin{array}{c}\text { video } \\
\text { surveying } \\
\text { and sampling }\end{array}$ & $\begin{array}{c}\text { surveying and } \\
\text { sampling }\end{array}$ \\
\hline
\end{tabular}


linking of video (snapshots) and photographs to these. Based on the dive reports and the video data, different seabed facies were recognised and mapped. It has to be noted that this facies mapping was mainly carried out from a geological and sedimentological point of view, hence that differences in faunal assemblages and ecological communities have not been recognised. All video data and photos, taken with the ROV and presented here, are under copyright of IFREMER. Finally, all the information was collected in the GIS projects (ArcView v3.2), which allowed a multidisciplinary interpretation.

\section{Results}

\section{Magellan and Hovland provinces}

\section{TOBI sidescan sonar mosaic}

In general, the Magellan/Hovland region appears on the TOBI sidescan sonar imagery as an area with a homogeneous acoustic facies of medium backscatter strength (Fig. 2). The intensity seems to decrease slightly from the north to the south, while the backscatter texture becomes smoother in that direction. This facies could be identified as bioturbated muddy or silty hemipelagic sediments, often with a watery or 'soupy' upper layer of a few $\mathrm{cm}$, containing a high concentration of foraminifera. The gradual change from north to south is probably due to a gradual change in grain-size, sorting and compaction of the sediments. In the Hovland province, the seafloor is cut by 6 elongated depressions or blind channels, generally running N-S (except for one which changes direction towards the NW; Fig. 2). They were also reported by Hovland et al. (1994) who attributed them to bottom current erosion or to the escape of pore water or gases through the seafloor. De Mol (2002) suggested they were caused by current scouring, and interpreted their elongation direction as the result of a northward-directed current. Apart from these channels and the obvious mounds with their associated, scoured moats, the seafloor appears relatively featureless. Evidence of recent erosion or sedimentation patterns, such as bedforms, is absent between these structures. A few pockmarks were found around $52^{\circ} 15^{\prime} \mathrm{N}, 12^{\circ} 30^{\prime} \mathrm{W}$ and around $52^{\circ} 04^{\prime} \mathrm{N}, 12^{\circ} 55^{\prime} \mathrm{W}$, but the overall environment of the Magellan and Hovland Mounds seems relatively quiet.

Against this background the coral banks are clear features: they have a strong backscatter on the flank facing the sidescan, reflecting their topography and their composition of (live) coral framework and coral debris (see below). An acoustic shadow can be seen behind the features. The Magellan Mounds are relatively small (some 300 to $800 \mathrm{~m}$ across, and up to some $50 \mathrm{~m}$ above the present-day seabed), and some of them are less easily recognisable (Fig. 3). These latter mounds are smoother, have a less strong backscatter and do not create a strong shadow. They are interpreted as being buried already under a thin drape of sediments. In total, 19 covered mounds could be found, while 14 mounds still seemed to be active at the present-day seafloor. Seismic studies however, have shown that the Magellan province contains many more mounds (possibly more than 1000 structures; Huvenne et al. 2003), but that most of these are buried already. 

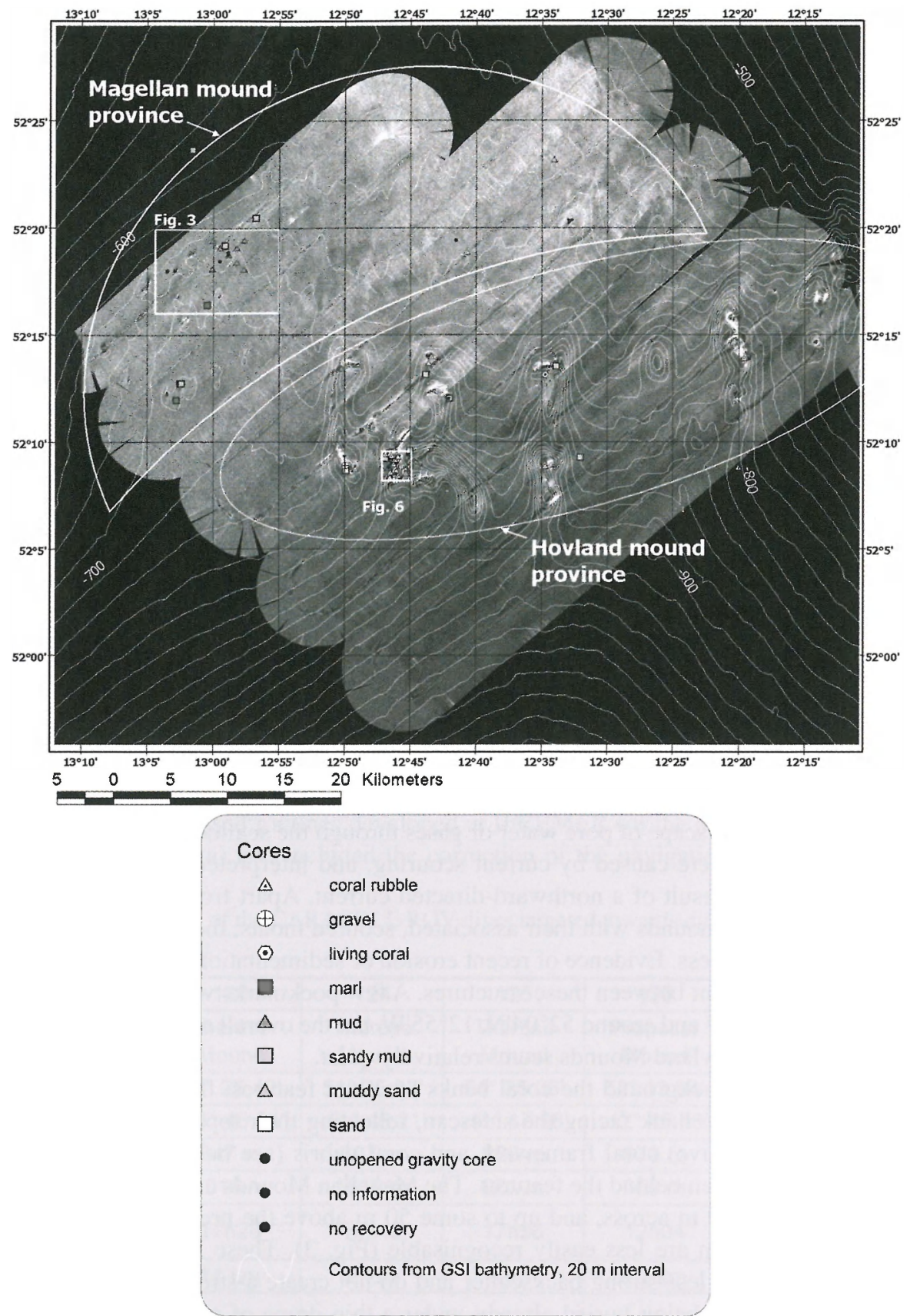

Fig. 2 TOBI sidescan sonar mosaic of the Magellan and Hovland Mound provinces. The bathymetric contours are derived from GSI data, and the core information was obtained from existing data sets, mentioned in the text. The rectangles indicate the positions of Figs. 3 and 6 


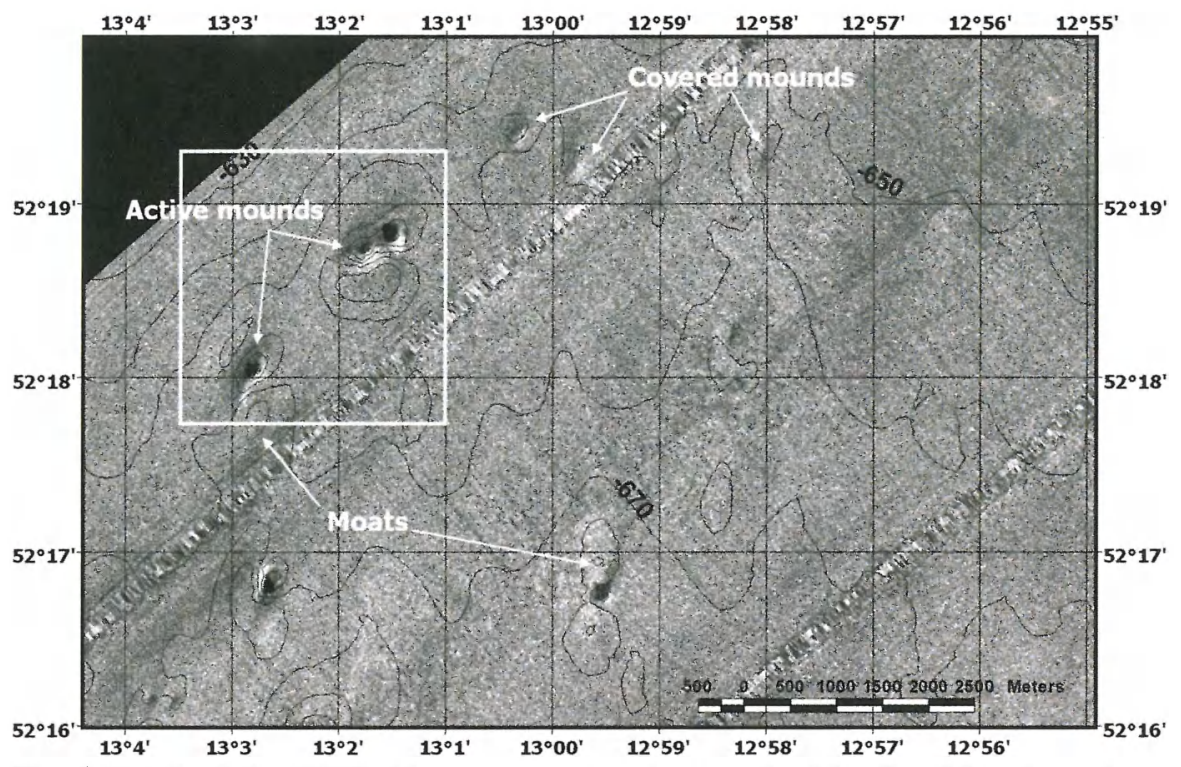

Fig. 3 Detail of the TOBI sidescan sonar mosaic over the Magellan Mound province, illustrating the seabed appearance of mounds and moats. Some of these are already covered by a drape of hemipelagic sediments. The bathymetry information is derived from the timedepth converted seafloor reflection mapped from 3D seismic data in the Magellan province (Huvenne et al. 2003). The box indicates the position of Fig. 4

The Hovland Mounds on the other hand appear to be much larger, and in several cases they form elongated ridges. Their length can vary between 1700 and 3200 or even $5000 \mathrm{~m}$, and their width ranges from 450 to $1200 \mathrm{~m}$. The ridges have different orientations and may be forked, with spurs extending in different directions. Still, often there is a north-south directed component (spurs, or the ridge itself). Eleven large and 15 smaller mounds could be recognised on the sidescan sonar mosaics. De Mol (2002) studied seismic profiles from the province which indicate that some of the mounds may have a common, subsurface base. He also found several buried Hovland Mounds. Most of the mounds are located at the flanks or at the heads of the elongated depressions in the area. They can be grouped in 2 clusters: one on the northeastern flank of the province and one more to the centre.

Depressions, described as 'moats' can be found around most of the mounds. They were previously recognised from seismic data already (De Mol et al. 2002; Huvenne et al. 2003), and were attributed to the scouring action of currents. Especially around the Magellan Mounds, the moats appear to be elongated in a N/S direction, possibly due to the action of a reversing current (Huvenne et al. 2003). And although most of these depressions are largely filled in nowadays, which indicates they might not be very active any more, with the help of the bathymetry data they still can be recognised in the sidescan images as subtle variations in backscatter (Fig. 3). Also some of the Hovland Mounds have associated moats to their south and north, which often merge with the $\mathrm{N}-\mathrm{S}$ trending depressions. The most western depression even seems to be formed through the merging of several moats (Fig. 2). 


\section{Mound Perseverance: a case study in the Magellan province}

Mound Perseverance, one of the few Magellan Mounds that actually reach the present-day seabed, is located at $52^{\circ} 18^{\prime} 3^{\prime \prime} \mathrm{N}$ and $13^{\circ} 2^{\prime} 48^{\prime \prime} \mathrm{W}$ (Fig. 4), at a depth of about $650 \mathrm{~m}$ on the western edge of the province. It is ca. $820 \mathrm{~m}$ long and 310 $\mathrm{m}$ wide and is elongated in a NNE-SSW-ly direction, towering some $50 \mathrm{~m}$ above the seabed. Seismic data indicate that its total height above its base is ca. $160 \mathrm{~m}$ (Huvenne et al. subm.). It was visited with the ROV together with another seabed protruding mound slightly to the northeast (Fig. 4). This second mound measures about $1000 \times 440 \mathrm{~m}$, and is directed in an ENE/WSW-ly direction. It is a double structure, with two summits at 33 and $55 \mathrm{~m}$ above the surrounding seabed. Its total height above its base is estimated as $145 \mathrm{~m}$ (Huvenne 2003).

Seven sedimentary facies were recognised on the video data of both mounds (Fig. 5):

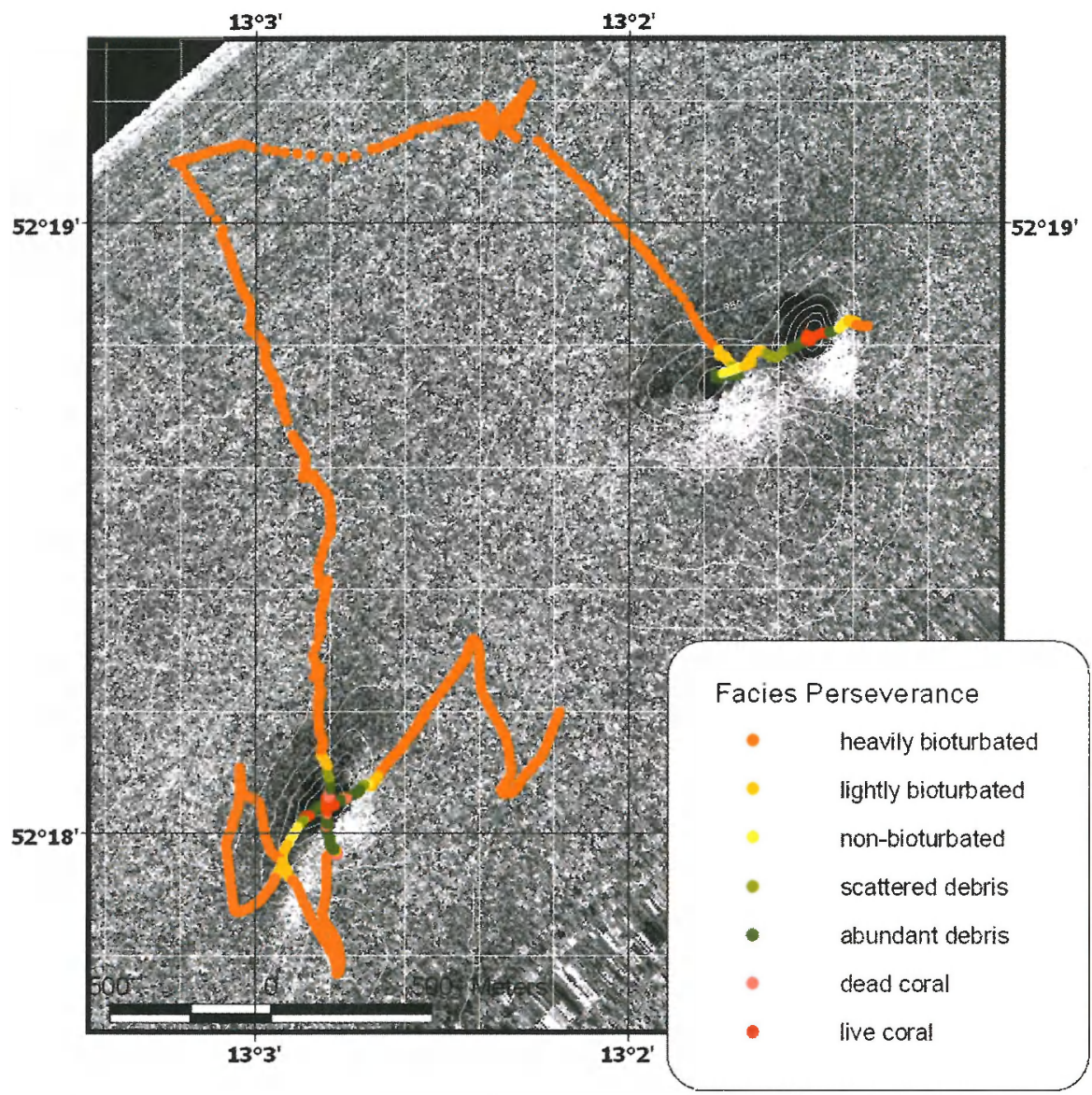

Fig. 4 Overview map and seabed facies interpretation of CARACOLE dive 127 on Mound Perseverance and a nearby Magellan Mound, overlaid on the TOBI sidescan sonar imagery. The bathymetric information is again derived from 3D seismic data (Huvenne et al. 2003) 
1. heavily bioturbated sediment (high concentration of burrows)

2. lightly bioturbated sediment (low concentration of burrows)

3. non-bioturbated sediment

4. scattered coral debris

5. abundant coral debris

6. dead coral (containing an open framework structure, devoid of sediment)

7. live coral
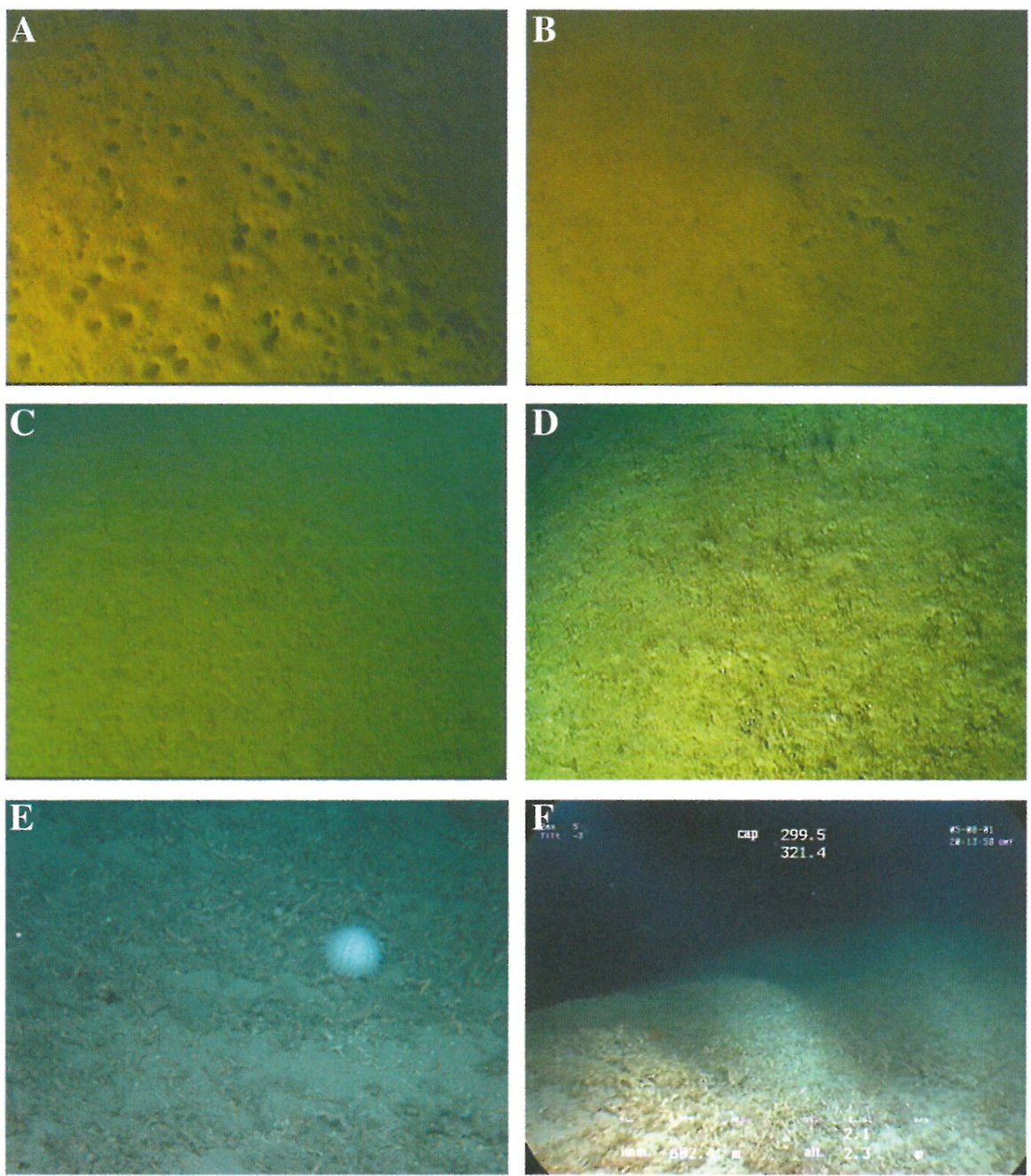

Fig. 5 Different seabed facies recognised on Mound Perseverance (Magellan province) and Propeller Mound (Hovland province): A heavily bioturbated sediment, B lightly bioturbated sediment, $\mathbf{C}$ non-bioturbated sediment, $\mathbf{D}$ scattered coral debris, $\mathbf{E}$ abundant coral debris, $\mathbf{F}$ dead coral 

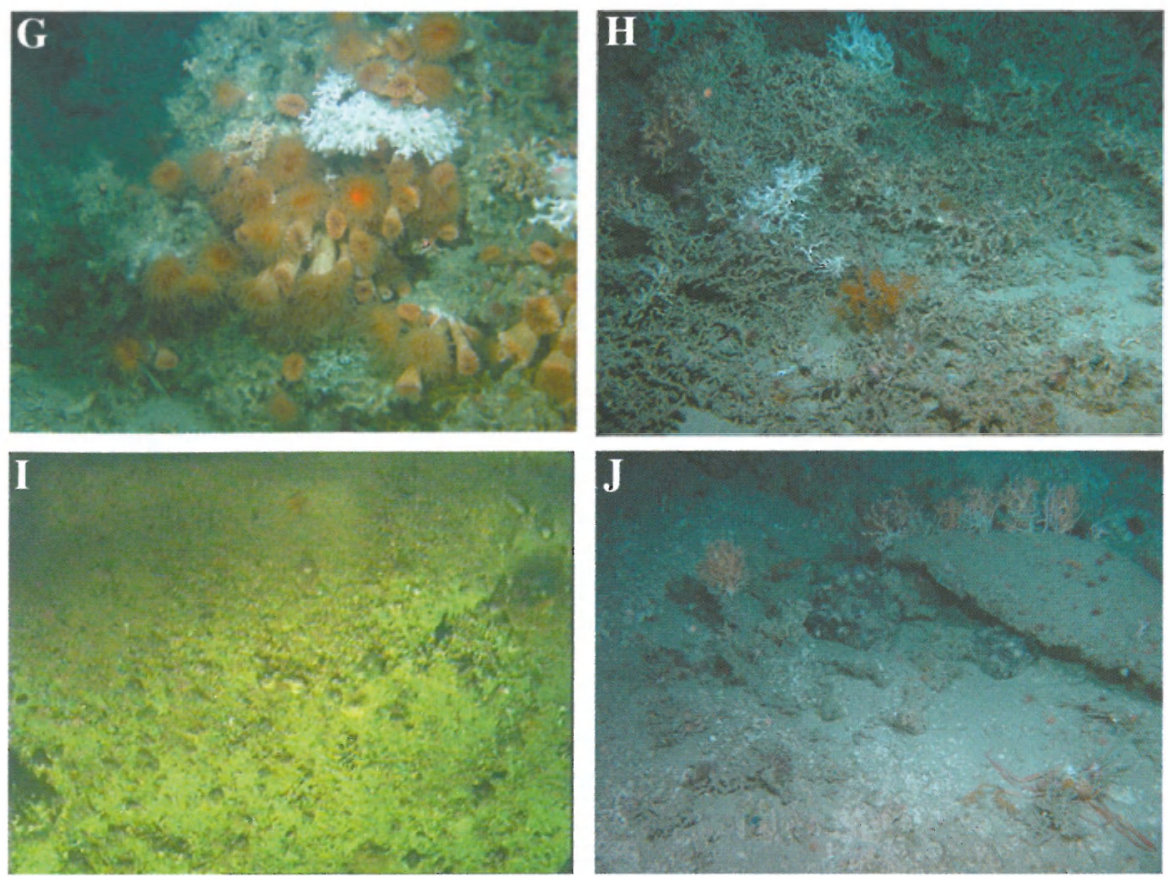

Fig 5 continued Different seabed facies recognised on Mound Perseverance (Magellan province) and Propeller Mound (Hovland province): G live coral colony on Mound Perseverance, containing Lophelia and Desmophyllum, H live coral on Propeller Mound, placed between dead coral framework, I gravel and pebble lag found on Propeller Mound, J part of outcropping crust and nanoplankton ooze found at the tip of the NE spur of Propeller Mound. All photographs with courtesy to IFREMER

The facies map (Fig. 4) shows that the largest part of the area is covered with bioturbated fine sediments. Only on the mounds themselves, coral debris, dead and live coral are encountered, causing part of the high-backscatter response on the TOBI imagery. Live corals are only found on the highest mound tops, or on a shoulder of Mound Perseverance. Lophelia pertusa and Desmophyllum cristagalli are the most abundant species, occurring in bushy colonies of some 1 to $1.5 \mathrm{~m}$ across and 0.75 to $1 \mathrm{~m}$ high (Fig. 5G). These are built of a framework of older (dead) material with live polyps at the outer shell, often facing the downslope direction (especially the Lophelia). The colonies occur in groups of 5 to 10 , generally situated in areas of coral debris with patches of plain sediment. They are not necessarily located between large amounts of dead coral as is the case, for example, in the Haltenbanken-Frøyabanken area or on the Sula Ridge off Norway (Mortensen et al. 1995; Freiwald et al. 2002). On most of the mound flanks, the transition from bioturbated sediments to the debris facies occurs at a depth of ca. $635 \mathrm{~m}$. Only on one of the flanks of Mound Perseverance this is not true (southern flank). The slope of the mound here makes a slight inward curve, and the seafloor comes closer to the 'core' of the mound. It seems that this flank has received less sedimentation. 
Another possibility could be that part of the coral debris was transported down along this flank as a small slope failure.

\section{Propeller Mound, an example of a Hovland Mound}

Propeller Mound is located in the central Hovland Mound province, at $52^{\circ} 09^{\prime} 48^{\prime \prime} \mathrm{N}$ and $12^{\circ} 46^{\prime} 24^{\prime \prime} \mathrm{W}$, and is so-called due to its shape in plan view (Freiwald et al. 2000). The mound has 3 spurs, and hence resembles the letter Y, or a propeller (Fig. 6). The recent TOBI survey revealed that the NW spur is connected to another long, NNESSW tending ridge (Fig. 2). This way it is the largest mound in the area, and in the whole of the Porcupine Seabight, with a total length of more than $5 \mathrm{~km}$. The width of the individual spurs is about $500 \mathrm{~m}$, and the top is located at a water depth of ca. $660 \mathrm{~m}$, while the mound towers about $140 \mathrm{~m}$ above the surrounding seafloor. More precisely the seafloor is dipping in the area, which causes the mound flanks to be considerably higher on the eastern than on the western side. From seismic profiles it is known that Propeller Mound reaches a height of about $280 \mathrm{~m}$ above its base (De Mol 2002). Furthermore, the mound is located at the head of one of the deepest depression in the province, being the blind channel that bends towards the northwest. This setting may well have influenced the mound development.

Towards the southeast of Propeller Mound, an extra complex of 3 irregular, smaller mound structures can be seen. They are probably linked at their base to the main mound, and reach ca. $90 \mathrm{~m}$ above the seabed.

Compared to the study of Mound Perseverance, one more facies was distinguished on the video images of Propeller Mound (Fig. 5):

\section{8. gravel, most probably a pebble lag of ice-rafted debris and dropstones}

On the whole, Propeller Mound shows a more complex scenario than Mound Perseverance. Bioturbated fine sediment again is the typical facies of the off-mound seafloor. It is only encountered along a few stretches of the dive track, as most of the dive was targeted on the mound top and flanks. Its occurrence however is less depth-related than on Mound Perseverance.

Live coral is found far more often than on Mound Perseverance. Again it is mainly concentrated on the tops of Propeller Mound and the smaller mounds to the SE, but also on the upper flanks (especially the western one) and on the ridge of the NW spur. Also on the tip of the NE spur some live coral is seen, related to an outcropping hardground and the exposure of some nanoplankton ooze (A. Freiwald pers. comm.) (Figs. 5J, 6). The top of Propeller Mound on the other hand is not fully covered with live corals, large patches of dead coral and coral debris are encountered as well. Live coral seems to occur in a similar way as on Mound Perseverance: forming bushy colonies, often with the live polyps all on one side. On the contrary, these colonies here are set between bunches of dead coral and coral debris (Fig. 5H). The most prolific occurrences of live coral are actually found on the tops of the smaller mounds to the SE. Lophelia pertusa and Madrepora oculata are the dominant coral species again, but Desmophyllum cristagalli and Stenocyathus vermiformis are found as well (Olu-Le Roy et al. 2002). 

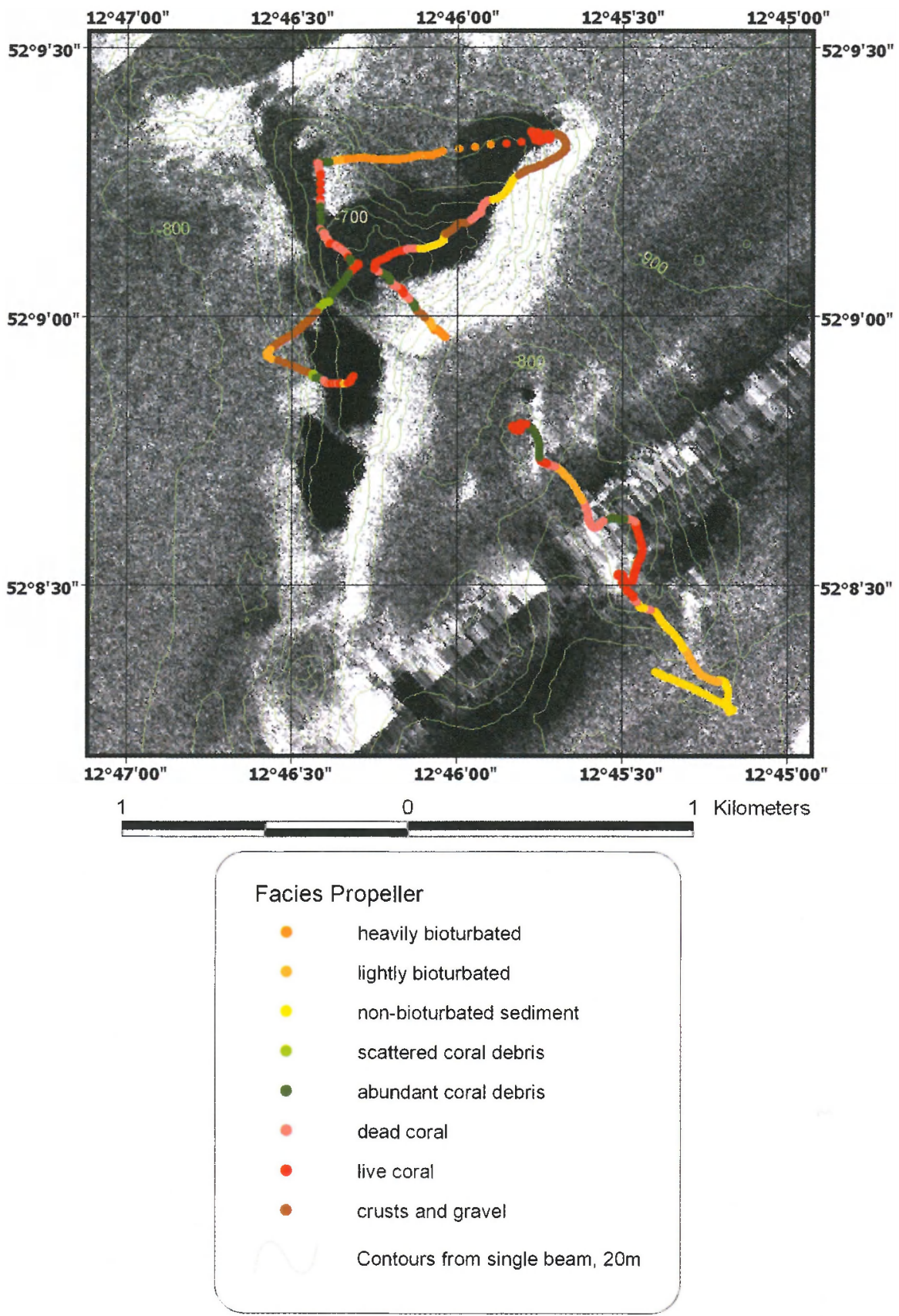

Fig. 6 Overview map and seabed facies interpretation of CARACOLE dive 126 on Propeller Mound, overlaid on the TOBI sidescan sonar imagery. The bathymetry information is derived from single beam data, obtained during a cruise with the R/V Poseidon in 2000 (Freiwald et al. 2000) 
Two remarkable observations were made: the occurrence of the hardground and nanoplankton ooze on the tip of the NE spur, and the fact that large parts of the dive were crossing grounds with facies 8 material: gravel and pebble lag, interspersed with sandy deposits. These facies seem to indicate erosion, and are mainly found on the middle flanks of Propeller Mound, especially on the eastern and western flank.

\section{Belgica province}

\section{TOBI sidescan sonar data}

The sidescan sonar mosaic of the Belgica Mound province shows an entirely different pattern compared to the Magellan and Hovland provinces (Fig. 7). The image is less smooth, which is partly due to the more irregular bathymetry of the area. First of all, the eastern slope of the Porcupine Seabight is steeper ( 2 to $3^{\circ}$ versus 0.2 to $0.5^{\circ}$ in the Magellan/Hovland area). Furthermore, the province is bound to the west by a blind channel that runs approximately north-south, bending towards the SE in the southern part of the TOBI mosaic. Between the mounds, the slope is cut by several small, downslope directed channels or gullies. Van Rooij et al. (2003) attributed the large channel to the action of a northward-directed bottom current, and interpreted the smaller gullies as minor turbiditic channels. The Belgica Mounds on their turn are often arranged 'en echelon', generally in north-south trending ridges, more or less parallel to the depth contours (especially to the south of the province). This way they create some sort of terrace-like morphology along the slope, as they tend to pile up sediments on their upslope flank (Wheeler et al. subm.). Their asymmetrical shape causes a lack of shadow formation when they are ensonified from the downslope direction. This, together with the fact that there are also other features with the same high-backscatter signature as the mound flanks facing the instrument, makes the mounds less easily recognisable than in the Magellan and Hovland province. In total 43 mounds were recognised in the combined sidescan sonar/bathymetry data set. This is similar to what is reported by De Mol (2002), who also found 20 more buried mounds on seismic profiles in the area. The mounds are between 300 and $2000 \mathrm{~m}$ wide, up to $100 \mathrm{~m}$ high above the present-day seabed and often have a slight NNE-SSW elongation (Wheeler et al. subm.).

Overall, three types of backscatter pattern were recognised in the Belgica province, besides a range of specific features and bedforms (Figs. 7-8):

A low backscatter facies of smooth texture (1) occurs mainly in the southern part of the TOBI mosaic. It also includes part of the large blind channel, and becomes darker (less backscatter) towards the south-east. On the echosounder profiles, a parallel-stratified sediment was found, with an acoustic penetration of locally up to $50 \mathrm{~m}$. The facies is interpreted as a package of hemipelagic sediments.

䊎 A high-backscatter facies of irregular texture (2) is found mainly in the central and northern part of the image, between the mounds and around the gullies. On echosounder profiles of these areas the penetration 


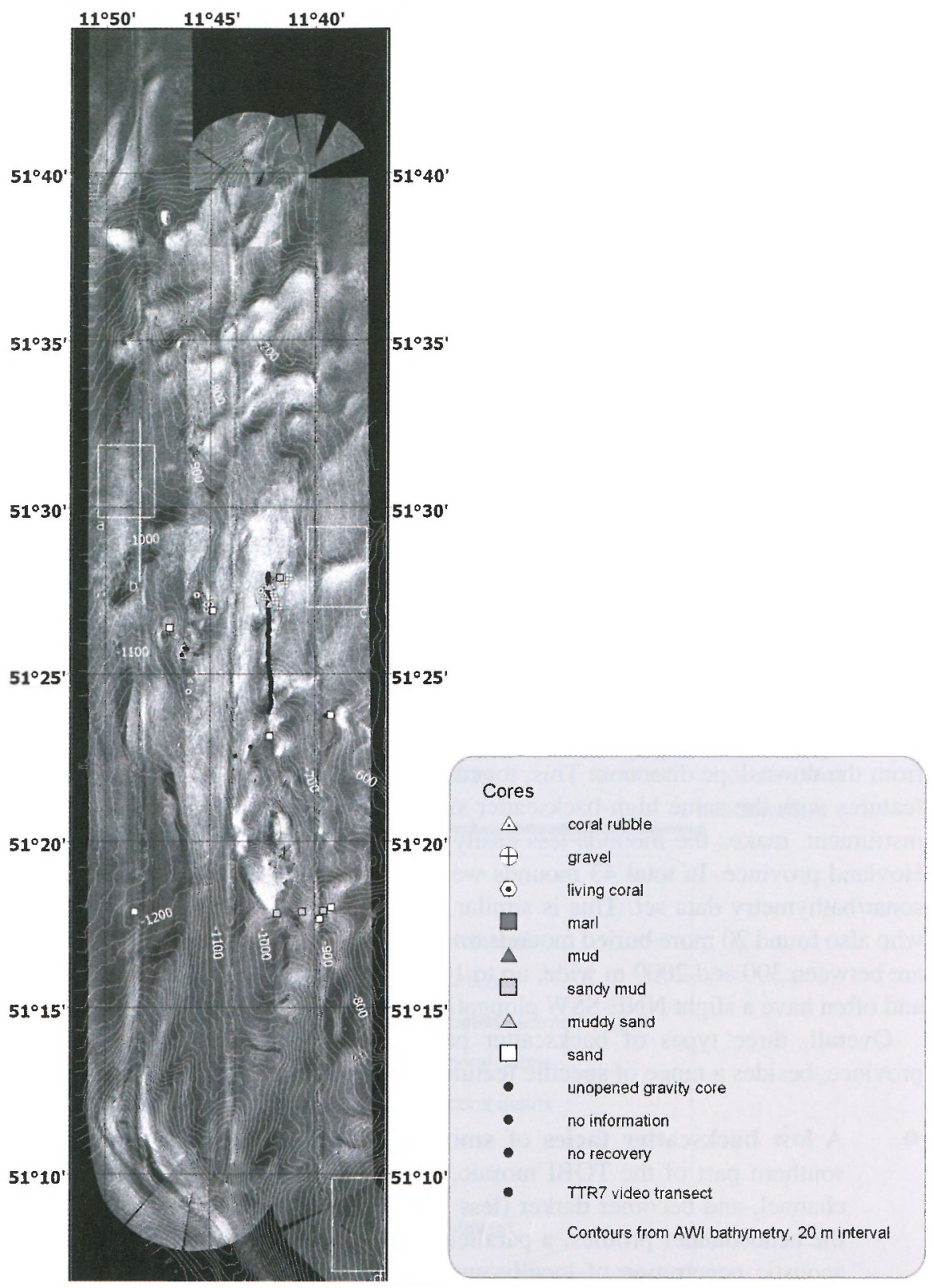

Fig. 7 TOBI sidescan sonar mosaic of the Belgica Mound province, with bathymetry data from the R/V Polarstern cruise (Beyer et al. 2003). Core information from different sources mentioned in the text. The TTR7 video transect was described by De Bergé (2000). The rectangles and line indicate the locations of the details presented in Figs. 9A-D 


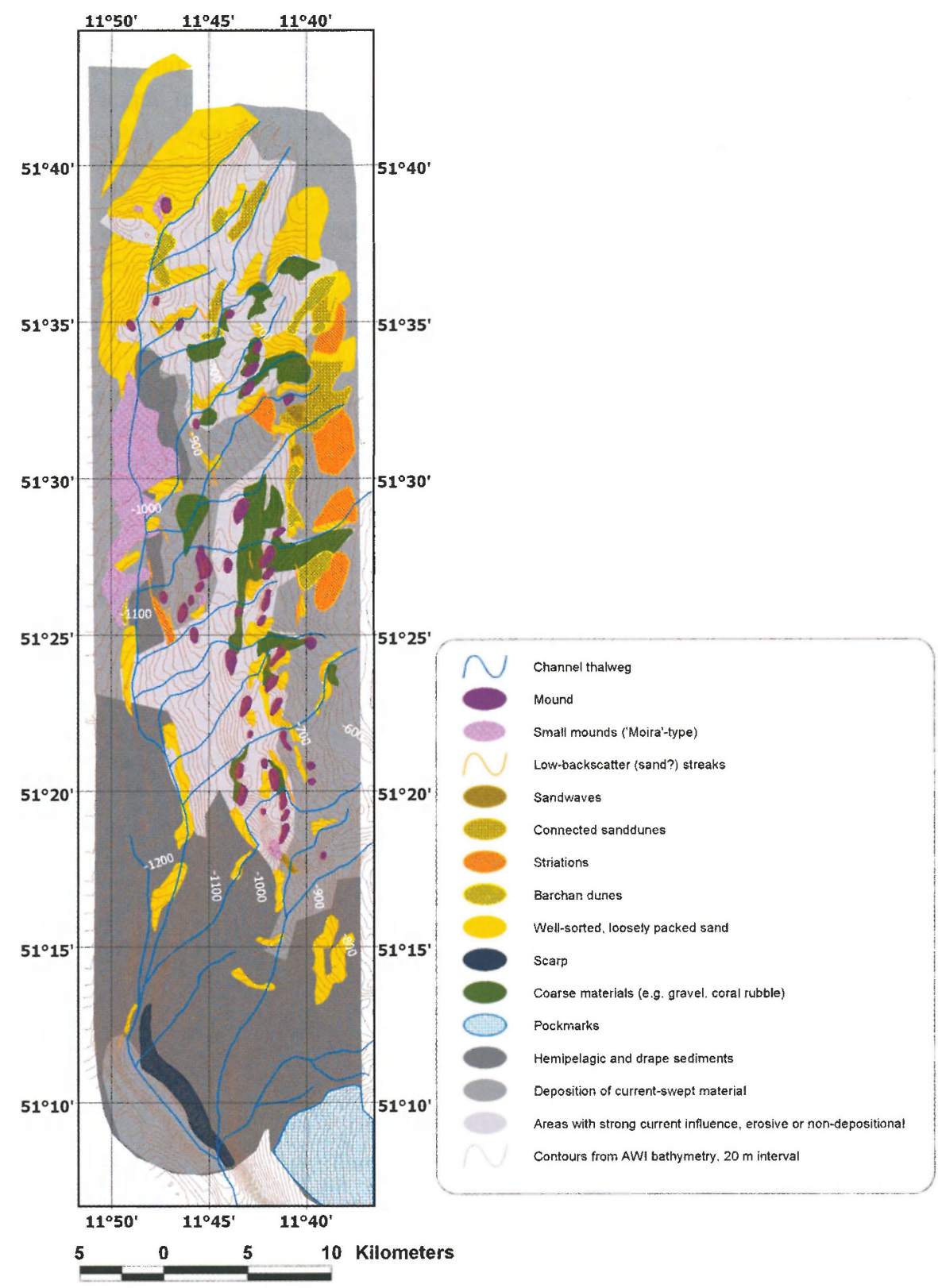

Fig. 8 Interpretation of the TOBI sidescan sonar and bathymetry data in the Belgica Mound province 
decreases a little to ca. $30 \mathrm{~m}$, and the amplitude of the seafloor and upper reflections is much higher, masking any underlying reflections. This facies is interpreted as indicative for current-swept areas, where the finest fractions are winnowed from the sediment and in some cases even non-deposition or erosion can occur. This results in a coarser, sometimes purely lag deposit. Core information describes foraminiferal sands and in some locations gravel or coral rubble.

A medium backscatter facies with irregular texture (3) occurs in the northern half of the TOBI image, more specifically east and west of the previous facies. It shows intermediate characteristics both on sidescan sonar and echosounder images. It is, however, also related to the area with irregular bathymetry, caused by the mounds and gullies. Therefore this facies is interpreted as an area with a higher sedimentation rate than estimated for facies 2 , but no drape sedimentation such as seen in facies 1 . It probably also exhibits some kind of sorting or winnowing effect, although less strong than seen in facies 2 .

It has to be noted that the boundaries between these facies are indicated more or less arbitrarily on the map, as in most places the facies change rather gradually.

Besides the overall backscatter pattern, some specific features have been recognised on the sidescan sonar records:

Mounds: the Belgica Mounds were described above.

Small positive, high-backscatter features: in some locations, especially in the northern part of the blind channel, slightly elongated (N-S) positive features of some 30 to $50 \mathrm{~m}$ wide can be seen (Fig. 9A). In these areas small (up to $10 \mathrm{~m}$ ), positive features can be identified on the echosounder data as well (Fig. 9B). Based on their similarity with a set of small mounds further to the east, these structures are interpreted as Moira-type mounds (Wheeler et al. 2000; Wheeler et al. 2005).

Towards the southeastern corner of the mosaic, a whole set of depressions is found, with an average diameter of $140 \mathrm{~m}$. Although no trace of them was seen on the echosounder profiles, they are interpreted as shallow pockmarks (Fig. 9C).

Patches with very high backscatter (apart from facies 2) were found between the mounds and along the north-facing slopes of the gullies on the upper slope (Fig. 9D). They are also interpreted as areas with a very coarse seaffoor, consisting of gravel lags or coral fragments. The echosounder profiles crossing the gullies show that the north-facing flanks are rather eroded, which may have caused the higher backscatter in these areas.

Patches of very low backscatter occur at several locations, especially on the south-facing slopes of gullies, the large channel, mounds etc. (Fig. 9D). In some cases they are sharply bound, in other locations their boundaries are rather fuzzy. On some of the patches zones with a wavy pattern of higher backscatter can be recognised. 


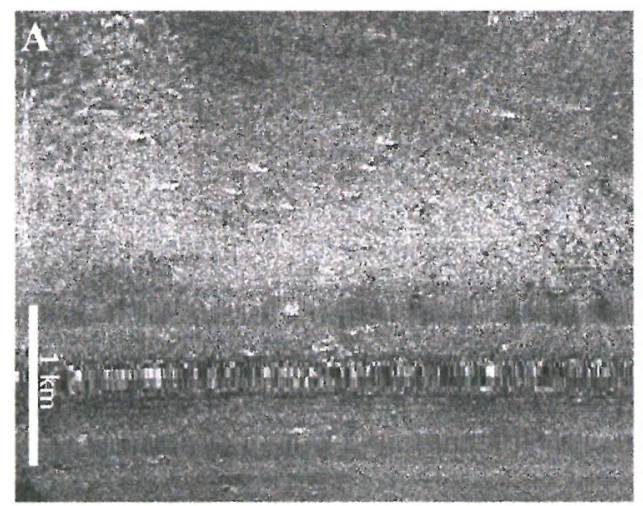

\section{$\mathbf{B}$}
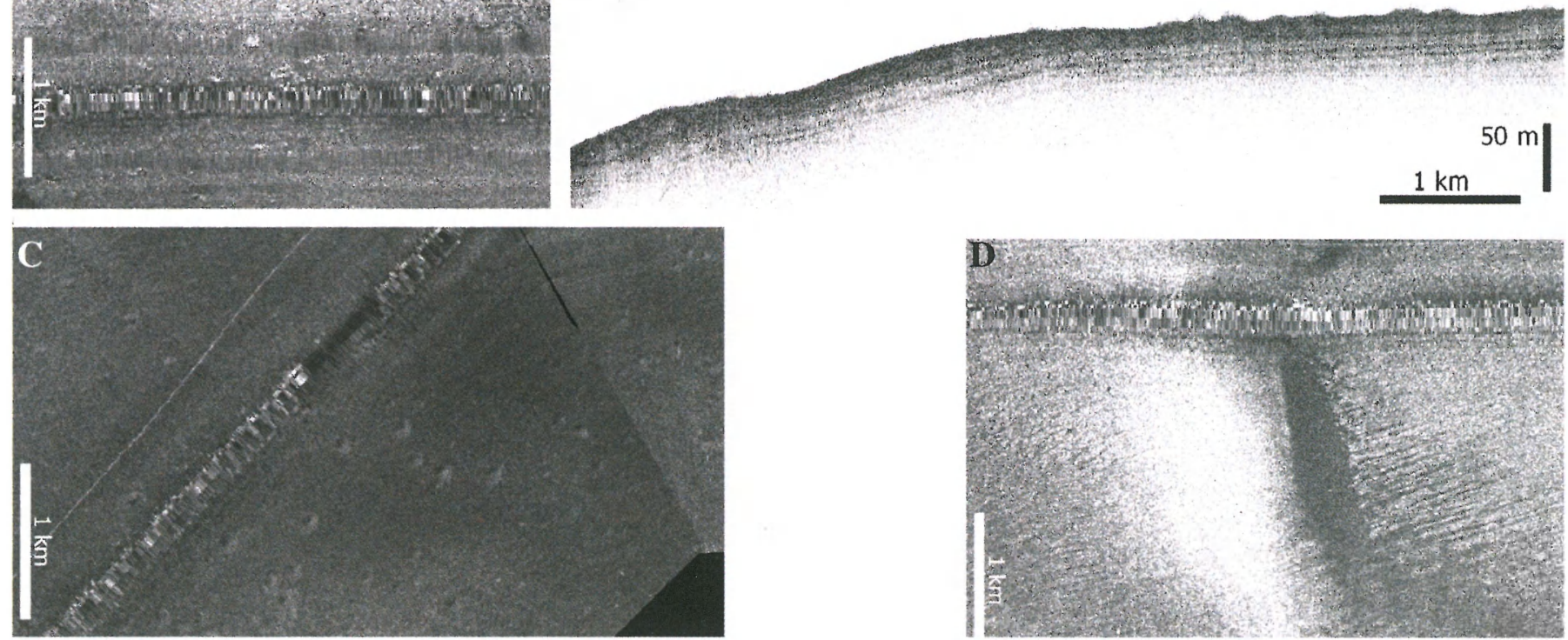

Fig. 9 Details of the TOBI sidescan sonar and shipboard $3.5 \mathrm{kHz}$ profiler data in the Belgica Mound province (locations indicated on Fig. 7). Small positive structures (A, B), interpreted as small mounds; pockmarks (C); and a detail of a downslope gully (D) with high backscatter on the northward facing flank, and very low backscatter on the southward facing flank, interpreted as well-sorted sands. Striations depart from this patch of low backscatter, and to the south of the gully, some barchan dunes can be seen, associated with the sand patch of a second gully further to the south 
* Striations: lines of very low backscatter placed on a high backscatter background are found at several locations, especially along the higher slope between the gullies (Fig. 9D). The lines are often directed in a NNW-SSE direction, and are mostly connected with/starting from a patch of very low backscatter. They can be up to 1500 or $2200 \mathrm{~m}$ long and up to $40 \mathrm{~m}$ wide.

Irregular patches of low backscatter on a high backscatter background exhibit different shapes, ranging from crescent-shaped to geometric patterns and spots of higher backscatter surrounded by lower backscatter lines. Some of these features occur directly besides a patch of very low backscatter, and gradually fade towards that signature.

Single low-backscatter streaks occur especially in the central part of the TOBI mosaic. They are up to $1500 \mathrm{~m}$ long and between 30 and $60 \mathrm{~m}$ wide. Overall, they are directed more or less N-S, and often they are linked to one of the patches of very low backscatter.

Based on ROV video observations and core descriptions of one very low backscatter zone east of Thérèse Mound (see below), this type of acoustic facies is interpreted as well-sorted, loosely packed sands. A similar interpretation was described by Masson (2001), who found a large area with very low backscatter on TOBI imagery from the Faeroe-Shetland Channel. Through ground-truthing with boxcores and photographs, they concluded that this facies was caused by a thin sheet of very well sorted sand or muddy sand, about 10 to $15 \mathrm{~cm}$ thick, covered with sand ripples. This interpretation can explain the other low-backscatter features in the Belgica province as well. Probably all of these bedforms are caused by sands, shaped by the currents and deposited on a coarser or a more compacted, higher reflective underlying seafloor. Both the striations and the individual streaks are current-parallel ribbons of sand. The crescent-shaped patterns can be interpreted as barchan dunes, up to $90 \mathrm{~m}$ wide, while the geometric patterns probably are caused by a dense pattern of barchan dunes, located closely enough to each other to be linked. The fact that all of these features occur very close to the deposits of sorted sands, supports the interpretation that these deposits acted as sediment sources for the bedforms to develop under the current action.

The overall pattern of bedforms and sedimentary features relates quite well with the descriptions of single sidescan sonar lines in the area (TTR7 and TTR8-records; Wheeler et al. 1998; De Mol et al. 1999; Huvenne et al. 2002). A more detailed description of the sedimentary environment in the Belgica province, based on highresolution sidescan sonar records, is given by Wheeler et al. (2005).

\section{Thérèse Mound as case study of a Belgica Mound}

The third case study, visited by ROV, is located at $51^{\circ} 25^{\prime} 44^{\prime \prime} \mathrm{N}$ and $11^{\circ} 46^{\prime} 15^{\prime \prime} \mathrm{W}$. Thérèse Mound is one of the most westerly mounds in the province, and hence also one of the deepest ones (Fig. 7). Its top is located in a water depth of $860 \mathrm{~m}$, while its flanks run down to about $950 \mathrm{~m}$ (eastern flank) resp. $1000 \mathrm{~m}$ (western, steeper flank). Hence the mound shows the typical asymmetrical shape of the Belgica Mounds, and reaches a height of ca. 100 to $140 \mathrm{~m}$ above the present-day seafloor. The mound is 
elongated in N-S direction, and measures 1250 by $650 \mathrm{~m}$. Seismic profiles indicate that it reaches a total height of ca. $190 \mathrm{~m}$ above its base (De Mol 2002).

Thérèse Mound is part of a small cluster of mounds (Figs. 7, 10), and another, smaller mound to the NE of Therèse was included in the ROV investigations during the CARACOLE cruise. It is about 550 by $350 \mathrm{~m}$ wide and reaches a height of about 50 to $70 \mathrm{~m}$ above the surrounding seafloor, with its top at $900 \mathrm{~m}$ water depth. It has its steepest (and longest) slope to the north. Apart from these 2 mounds, the ROV dives were extended even further to the east, in order to investigate a few small structures recognised on high-resolution sidescan sonar imagery, and interpreted to be small mounds as well ('Moira Mounds'; Wheeler et al. 2000). They are discussed in detail in Wheeler et al. (2005).

In total 3 ROV dives were carried out on Thérèse Mound and its surroundings (Table 1). Opderbecke and Pitout (2001) and Hinsinger (2002) processed the highresolution multibeam data collected during the first dive, and integrated this data set in a $3 \mathrm{D}$ model of the mound. From their results it appears that the elongated mound has a fairly sharp ridge crest over its southern half, while the northern part of the mound appears a little lower and more rounded or concave. The flanks are covered with waveforms, with a general E-W strike direction and sinuous, bifurcating crests. They have an average wavelength of some 10 to $12 \mathrm{~m}$, and are 0.5 to $1.5 \mathrm{~m}$ high. They can be interpreted as sediment waves and could indicate the influence of a northward or southward current. Virtually the whole mound is covered with them, except for the steepest part of the western upper flank, just beneath the mound crest. It must be noted that the waveforms on top of the mound are mostly covered, and hence now stabilised, by coral.

The facies definitions and mapping of Thérèse Mound were partly based on the work of Dekindt (2001). A more extensive description of the video data is also given in Wheeler et al. (2005), as part of the detailed analysis of local sedimentary processes in the Belgica Mound province. In total, 6 different facies were recognised in the video data here. They differ a little from the facies definitions used in the previous two case studies, as the environment around Thérèse Mound differs so much from the Hovland and Magellan Mound provinces (Fig. 11). The following facies types were found:

1. sandy sediment (without faunal occurrence)

2. coral debris

3. dead coral

4. limited amount of live coral (on average 25 to $30 \%$ of the video coverage)

5. abundant live coral (on average 65 to $70 \%$ of the video coverage)

6. live coral sitting between rippled sand

The resulting facies map (Fig. 10) shows a very large abundance of coral (live, dead or debris). Only in the eastern part of the dives, rippled sands are found. The richest coral areas, with the highest amount of live coral (and its associated fauna) are found on the highest parts of Thérèse Mound and the smaller mound to the 

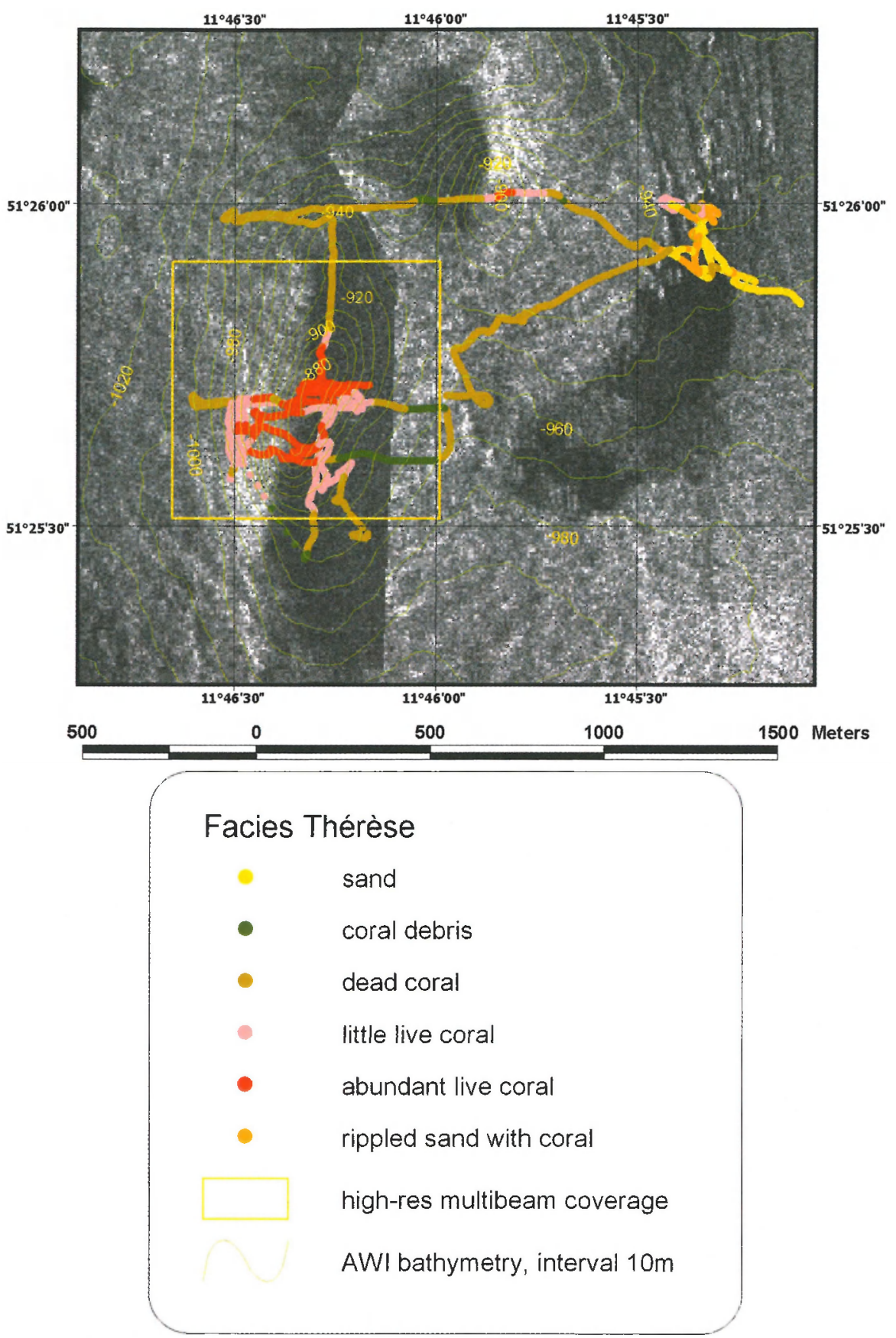

Fig. 10 Overview map and seabed facies interpretation of CARACOLE dives 124 and 125 on Thérèse Mound, overlaid on TOBI sidescan sonar imagery. The bathymetry information is extracted from the data collected during the $\mathrm{R} / \mathrm{V}$ Polarstern cruise 
northeast. Especially on the western upper flank of Thérèse Mound, a large field of abundant live coral is located. It has to be noted that this is the area where no sediment waves were encountered on the multibeam map (Hinsinger 2002). These areas of abundant live coral occurrence (facies 5) are very rich. Corals occur in thick bunches, and no patches of sediment can be seen between them. The main coral species on Thérèse Mound are Lophelia pertusa and Madrepora oculata again,
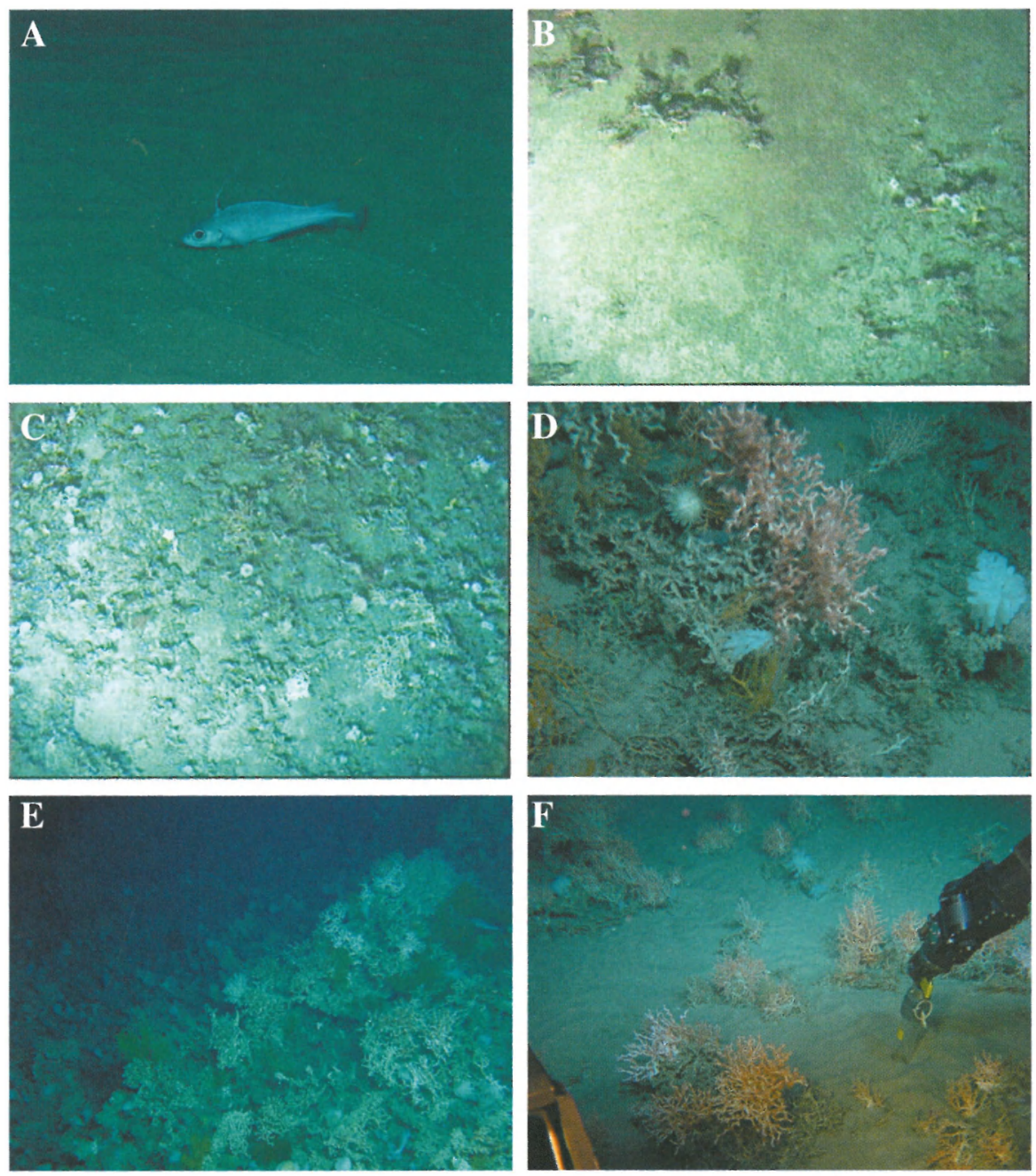

Fig. 11 Different seabed facies recognised on Thérèse Mound and its surroundings: A rippled sand, $\mathbf{B}$ coral debris, $\mathbf{C}$ dead coral, with a high abundance of sponges, $\mathbf{D}$ limited amount of live coral, $\mathbf{E}$ abundant live coral, $\mathbf{F}$ live coral sitting between rippled sand. The abundant live coral $(\mathbf{E})$ is sitting on a steep flank, and the morphology of large-scale waveforms can be seen underneath the coral framework. Note also that the direction of the ripples between the corals (F) is variable, showing how the bottom currents are deflected by the coral colonies. All photographs with courtesy to IFREMER 
but also large amounts of cnidaria and sponges were found $(\mathrm{H}$. Zibrowius and $\mathrm{A}$. Freiwald pers. comm.). Several cables and lost fishing nets were hooked between the corals, and in some locations the framework was damaged. Evidence of trawling activities between the Belgica Mounds is also given by Wheeler et al. (2001). It indicates the importance of the rich faunal community, associated with the mounds, attracting fishing activity in the area.

The areas of dead coral framework are very extensive. The northern, more rounded part of Thérèse Mound shows a large area of dead coral, and towards the east a vast plain of dead coral is located as well. Remarkable is the high abundance of sponges (Aphrocallistes sp.; J. Vacelet pers. comm.) in these areas, which seem to have colonised the dead coral frameworks. However, in many cases only the sponge skeleton is left, indicating that also for them the environments are not optimal any more (Dekindt 2001). Between the coral frameworks patches of (non-rippled) sediment can be seen.

On the eastern flank of Thérèse Mound, large sediment waves were seen on the video records, which correspond to the waveforms identified on the multibeam bathymetry data (Hinsinger 2002). On the upper slope they are fully covered with (live) coral, but further down the slope the corals seem to prefer the wave crests or the south-facing flanks of the waves. The troughs and the north-facing flanks contain coral rubble and patches of sandy sediment. Further towards the east, the less and less live coral can be seen, and the patches of sediment show some ripple marks. Some of these sediment waves are quite steep, as their slope is supported by the coral framework. They are interpreted as relict features, as they are overgrown by corals.

The sandy sediment of facies 1 consists of well-sorted, loosely packed sands, causing the patches of very low backscatter on the TOBI sidescan sonar images. The nature of the sand is not known, but it probably contains a large amount of foraminifera, as is reported for the upper sediment layer elsewhere in the area. Generally these sands are rippled, with ripples having a wavelength in the order of $10 \mathrm{~cm}$ and a height in the order of $1 \mathrm{~cm}$ (Wheeler et al. 2005). Besides the ripples, sandwaves of larger scale can be recognised on the video data of the same area. Their size (estimated roughly from the video images) seems to match the size of the sediment waves revealed by the high-resolution multibeam image further to the west. Most of them also have an E-W strike, indicating again a northward or southward current. Recent additional observations with a multibeam system mounted on the ROV Victor 6000 have confirmed the presence and pattern of these sandwaves (Foubert et al. 2005).

The zone with facies 1 and 6 takes a particular position in these ROV dives. The small structures seen on high-resolution sidescan sonar data (Wheeler et al. 2000) and described as small positive structures from the TOBI sidescan records indeed proved to be small mounds, called 'Moira Mounds'. As stated above, these are described in detail by Wheeler et al. (2005). 


\section{Discussion}

\section{Different environments}

The sidescan sonar and ROV data presented here clearly show the very different seabed environments in the Belgica and Magellan/Hovland Mound provinces. Similar results were also reported by Huvenne et al. (2002), who found that image texture analysis of selected OreTech sidescan sonar details in the Hovland and Belgica provinces revealed considerable differences in terms of textural homogeneity and entropy. This points to actual differences in the nature of the sedimentary environment between the two provinces, which affect the present-day development of the mounds in these areas.

The Belgica Mound province appears to be a much more dynamic environment than the Magellan and Hovland provinces. Many different types of bedforms are encountered in this area, sediments are coarser, the bathymetry is more irregular and the province is located on a steeper slope. All this indicates a stronger influence of local bottom currents. The highest residual currents at the seabed in the Porcupine Seabight were indeed measured along the eastern slope $(11 \mathrm{~cm} / \mathrm{s}$, at $8 \mathrm{~m}$ above the seabed, in a NNW-ward direction; Pingree and Le Cann, 1989), while mean values for the northern Porcupine Seabight do not exceed $5 \mathrm{~cm} / \mathrm{s}$ (White 2001). Additionally, Pingree and Le Cann $(1989,1990)$ found evidence for strong diurnal tides on the eastern slope of the Porcupine Seabight with maximum instantaneous current speeds of $54 \mathrm{~cm} / \mathrm{s}$ in a northerly direction. Rice et al. (1990) indicated that the seabed slope in this area is also close to the characteristic slope of the $\mathrm{M}_{2}$ internal tide, and hence that local enhancement of bottom currents, associated with increased turbulence in the water column, is likely. De Mol (2002) also mentioned the role of the interface between the ENAW and MOW, possibly contributing to this effect. These tidal effects may influence the creation of the bedforms, or may play a role in the formation of the ripple patterns in the sandy areas, such as the Moira Mound area. In any case they add to the overall turbulence and dynamics of the Belgica Mound province.

Moreover, the overall image of the sedimentary pattern and bedform occurrence in the Belgica province, as it is described above, fits very well with the observations of a northward directed slope- or bottom current. As suggested by Van Rooij et al. (2003), this current is probably focused along the blind channel in the southern part of the area, creating deep scouring there, and allowing hemipelagic sedimentation in the adjacent areas. Further to the north, where the channel becomes shallower, the current might spread over a wider area. This results in local current intensifications between the mounds and the creation of coarser lag sediments. The finer fractions are winnowed out, and are partly deposited besides or towards the north of the source areas, in locations with a facies-3 backscatter pattern. Where the northward current meets an obstacle (such as a southward facing flank), the heaviest particles of the bedload cannot be transported any further, and are deposited in patches of well-sorted sediments (sands). On the opposite flank of the downslope gullies, erosion occurs. A similar process was suggested by Flood (1988) and by Masson et 
al. (2002) to explain the formation and migration of sediment waves of mixed grain size composition under contour currents. Hence the very low backscatter patches are witnesses of a fairly continuous, long-term process.

The other features, for which the sand deposits are the sediment source, such as the striations or the sediment waves around Thérèse Mound, also point to a N/ $\mathrm{S}$-directed current influence. The morphology of the barchan dunes specifically indicates a northward current. However, these bedforms might be created by more instantaneous events. For example, on tidally influenced shelves, a mean peak spring near-surface current of ca. $100 \mathrm{~cm} / \mathrm{s}$ would be necessary to create the striations (sand ribbons), while for the barchan dunes some $75 \mathrm{~cm} / \mathrm{s}$ would be sufficient (Stride 1982). The necessary currents at the seabed seem to be a little lower; Wynn and Stow (2002), for example, suggest that values of $40 \mathrm{~cm} / \mathrm{s}$ would be sufficient to create barchan dunes on the continental slope. Still, this value is much higher than the average residual current speed in the Belgica province, which indicates that the barchan dunes and striations are not formed during a continuous process, but are rather related to the episodic peak current speeds caused by the tidal processes.

Some of the bedforms could also be fossil features, created by a higher current speed some time ago. The overgrown sediment waves on Thérèse Mound are a possible example of this. However, they are probably still of post-glacial origin, because the current speeds in the area were strongly reduced during glacial times, as is indicated by the much finer glacial deposits found in gravity and piston cores (Foubert 2002; Van Rooij et al, subm.). The other features linked to the patches of well-sorted sands, seem to be more recent.

Compared to this current-influenced area, the Magellan and Hovland provinces are much more quiet. No bedforms are found, the sediment is finer, is bioturbated and watery, related to the lower overall current speeds. However, higher current speeds must have affected the area before, as is seen from the moat formation around both Magellan and Hovland Mounds and from the scouring of the blind channels/elongated depressions in the Hovland province. Probably tidal currents may have played a role in some of the scouring processes: due to the circulation around the Porcupine Bank, the present-day diurnal tidal currents in the area are enhanced, especially at the seabed, in a N-S direction, the elongation direction of the moats (Mohn et al. 2002). However, they are not strong enough any more to create any reasonable amount of scouring around the mounds: the moats are slowly filled in. This is illustrated by seismic profiles (Huvenne et al. 2003), by the smooth backscatter pattern on the sidescan sonar images and by the facies mapping: the moats contain the same type of bioturbated fine sediment as encountered elsewhere in the sedimentary areas of these two mound provinces. It appears that since the initiation of the mounds, probably in (Late) Pliocene times (De Mol et al. 2002; Van Rooij et al. 2003), the northern Porcupine Seabight gradually became quieter, and that, in general, the amount of current influence during the development of the mounds decreased.

Overall, it may be clear that throughout the development history of the mounds, the water mass structure and associated current regimes in the Porcupine Seabight, 
together with the sedimentation patterns, have changed considerably. For example, one of the most prominent factors influencing the oceanographic and sedimentary conditions in the North Atlantic during that time interval, is the climatic variability associated with the glacial and interglacial cycles. Schönfeld and Zahn (2000), for example, argue that during the last glaciation, the pattern of the MOW along the European margin was seriously different compared to the present situation, and that this water mass did not occur north of Spain. Such a switch-on and switch-off of the MOW in the Porcupine Seabight region must have had severe consequences for the development of internal tides, for example, or for the circulation along the Porcupine Bank, due to a change or disappearance of the ENAW/MOW interface and a change in the density structure of the water column. Also the characteristics of the ENAW itself will have changed under the different climatic conditions. Hall and McCave (1998) and Foubert (2002) report a current reduction and higher sediment input during glacial times in the area, witnessed by a higher sedimentation rate and finer deposits. Other changes in sea level or in density structure may also have affected the seabed environment in the area since the Late Pliocene. A complete understanding of the paleoceanography and of the reason why the mound environment in the northern Porcupine Seabight became quieter, will require much more research effort.

The only place in the Magellan/Hovland provinces where some non-deposition can be found on the present-day seabed, is along one of the channel flanks in the Hovland province. This is the only serious difference observed in the presentday sedimentary environment between the Magellan and Hovland provinces: the presence of the channels, which probably still focus the limited bottom currents in the Hovland area. De Mol (2002) showed from seismic profiles that channels and erosional depressions have been present in this area for a long time, and therefore are a key feature distinguishing both provinces in general. The Hovland Mounds are specifically located along these channels and depressions, and could benefit from the enhanced currents. Scouring in the Magellan province only happened as a result of the presence of the mounds, and it appears that current enhancement in this area never reached the same levels as in the depressions/channels in the Hovland province. This may have been an important factor explaining why the Hovland Mounds could develop to much larger structures, and could escape early burial as happened with the Magellan Mounds.

\section{Stages of mound development}

Because the Porcupine Seabight has such different environments, also mounds with a very different appearance can be found. They can be interpreted tentatively as different stages of mound development:

Possible incipient mounds: the Moira-type mounds could be considered as an example of incipient mound structures, or at least as an example of coral expansion or (re)colonisation of a new area. The small mounds, only a few metres high, seem to have initiated fairly recently: the $3.5 \mathrm{kHz}$ profiles through small mounds show parallel stratification directly under the structures at the seabed (Fig. 9B). 
Therefore it appears that these mounds are very shallow, and not rooted deeper in the sedimentary sequences. Possible processes behind their formation are outlined by Wheeler et al. (2005).

It has to be noted, however, that the finding of these mounds of presumed initial stage is a remarkable fact, as no other examples of mound initiation have been recognised on seismic records of the area (De Mol et al. 2002). It is possible that other Moira-type mounds were formed in previous times, but became buried quickly, before they could reach a considerable height. It is also possible that a specific sediment/current environment is necessary. Other coral colonies do not expand vertically into initial mounds, and even do not survive for a very long time (e.g., the extended area of dead coral east and north of Thérèse Mound).

A fully 'active' mound: once small mounds have survived the initial stages, they might develop further, and expand until they reach a stage in which they form large structures on the seabed, carrying a healthy, rich faunal community, based on coral species such as Lophelia and Madrepora. Thérèse Mound is an example of such a 'grown-up' individual. On the western upper flank of this mound large amounts of live coral and associated fauna were found. However, the vast areas of dead coral on the northern part of the mound indicate that also Thérèse Mound has known even more prolific times. The position of the live corals again is closely related to the current pattern around the mound: the western upper flank is the steepest part of the mound, and may therefore have the highest current speeds. This was confirmed during the ROV dives: the southern part of the mound, and especially the western flank, was the area where the instrument had the highest difficulties to stay on track, as a result of the currents (Olu-Le Roy et al. 2002).

The coverage of nearly the entire mound with sediment waves is an enigmatic observation. As stated above, most of these bedforms are relict features, because they are overgrown with corals and coral framework material. They imply that there was a period, before the present-day coral growth, when mobile sediment was reworked and/or deposited on the flanks and the northern ridge of Thérèse Mound. It is possible that the process of sediment dynamics reached as far to the east as the area of the Moira Mounds, and even beyond, as sediment waves have been found there too. It is however also possible that these waves were formed in a similar, but later process, because they are not yet overgrown. To what extent these processes of sediment wave formation were the result of changing environments at, for example, glacial/interglacial boundaries, related to the reintroduction of the MOW in the area and the establishment or shift in the interface between the MOW and ENAW, is as yet unknown, and asks for more detailed sedimentological studies. After the deposition of the sediment waves, corals have colonised the flanks of Thérèse Mound again, first choosing the most favourable places: the ridge crests of the waves, and their upcurrent flanks. Higher up the slope the corals and fauna could even spread over the entire waveforms. However, they preserved the morphology, and in some places maybe even enhanced it, by growing preferentially on the ridge crests, and reinforcing these with their framework structure.

It is remarkable that in the area where no sediment waves were mapped, on the upper western flank of Thérèse Mound, the coral life seems to be most abundant. It 
is possible that this area was too steep, and hence currents were different, resulting in no formation of sediment waves. It is also possible that the prolific life in the meantime has smoothed out all traces of bedforms. One could also wonder if there was a similar pattern of coral growth on Thérèse Mound before the deposition of the bedforms. If that was the case, the rich communities on the upper western flank probably inhibited the deposition of well-shaped sediment waves, and baffled most of the sediment between the coral framework. From that point of view it is then tempting to see this area as the origin from where the recolonisation of the sediment waves could start, under a process similar to that seen nowadays around the Moira Mounds.

It has to be noted that similar waveforms were observed during two ROV dives (CARACOLE cruise) on a mound in the Logachev province, Rockall Trough (OluLe Roy et al. 2002). In that area the mounds and waveforms are fully covered with corals and coral framework. Wheeler et al. (subm.) suggest that the waveforms could also be built by the coral colonies, arranging themselves in a lined-up pattern that could be beneficial for their food supply. The waveforms in the Belgica province however seem to be rather related with the sedimentary processes in the area, as sediment waves of similar dimensions and with similar E-W strike have been found in large parts of the province (e.g., De Mol et al. 1999).

A mound 'on retirement': an example of a mound that is not at its full strength any more, and that slowly might 'give up', is Propeller Mound. There is still some live coral, but it is rather scattered over single colonies or thickets, set between bunches of dead coral. There seems to be, by far, a poorer biological community in comparison with the upper flanks of Thérèse Mound. The live corals again have chosen the more elevated or exposed positions, trying to profit from an enhanced current at the mound ridges or the tops of the spurs.

The outcropping crust and nanoplankton ooze at one of these spurs seems to indicate some amount of erosion within the (recent) past. Also the gravel and dropstone facies originated from winnowing of the fine sediments, and points to a certain amount of erosion. This is confirmed by recent datings of corals in gravity cores on Propeller Mound (Dorschel et al. subm.). Large hiatuses are found in the stratigraphy of the on-mound cores, while in off-mound cores (from the moats or from even further away), these hiatuses were not present. Both the fully glacial and the peak interglacial sediments appear to be removed from the mound, leaving only interstadial strata (Rüggeberg et al. subm.). In some places on the mound slope, the coral rubble at the surface of Propeller Mound has ages of $140 \mathrm{ka}$ and more (Dorschel et al. subm.). Most probably these coral fragments have been exposed due to erosion, or were exposed higher up the mound, and have moved down along the steep slopes.

On the whole, many of the Hovland Mounds appear very similar to Propeller Mound. Several of them have spurs, probably due to the current action shaping them. The largest mounds are located close to the channels, indicating that these probably were substantial in the focusing of enhanced currents. It appears as if most of the Hovland Mounds, although not at their full strength any more, have managed to avoid complete burial thanks to their size. They reach high enough above the 
seabed to create some extra current enhancement, and in this way to preserve some coral cover.

A mound about to die: the fate of Mound Perseverance (despite its fierce name) seems to be quite clear. If there are no changes in the sedimentation or current patterns in the Magellan province, this mound will end up in the same situation as the other Magellan Mounds: buried by the hemipelagic sediment. Most of the material encountered is debris or dead coral, often covered already with a thin veneer of sediments. The live coral which is present can only be found at the mound top or on a spur, and consists of a few meagre thickets. However it is striking that these thickets are placed on a surface of coral debris, and not amidst bunches of dead coral. They could be the last few bits of coral surviving on the mound, or may have just recolonised the coral debris, on which they could find a hard substrate to start growing. Again one can wonder if part of the debris is older material, exposed by a phase of erosion. However, the present-day process clearly is one of sedimentation, shown by the bioturbated sediment covering the lower flanks of the mound and the moats. It probably causes the clear depth-dependence of the different facies on the mound, a characteristic absent on Propeller Mound for example, because of its complex shape, its position at the head of a channel, and its interaction with the limited bottom currents.

The different stages of mound activity presented above, illustrate that both phases of erosion (such as on Propeller Mound) and deposition (such as on Thérèse Mound, creating the sediment wave patterns) can occur on mounds. Dorschel (2003), for example, presents a model of phased mound growth for Propeller Mound, explaining the hiatuses found on that coral bank by periods of erosion. From that point of view, one could expect that, if the oceanographic and environmental conditions became more favourable again for abundant coral growth in the Hovland province, the mounds would soon be recolonised, as there are many hard substrates available for the corals to settle. However, outside the mounds, in the homogeneous fine sediment areas, coral settlement would be less easy, and the Hovland Mounds would form islands surrounded by hemipelagic sediments. A similar conclusion can be drawn for the Magellan Mounds, which are even smaller and hence would experience more difficulties for recolonisation. The Belgica province on the other hand offers plenty of settling grounds (coarse lag deposits, coral rubble), and the irregular bathymetry provides many local highs where currents can be enhanced.

\section{Conclusions}

The first analysis of the TOBI sidescan sonar mosaics and ROV Victor 6000 video imagery of the Porcupine Seabight reveals that the present-day environment is markedly different in the three provinces of coral banks in the area. Especially between the north and the east of the Seabight there is a clear difference, with more quiet, hemipelagic conditions in the Magellan and Hovland provinces and a more dynamic environment in the Belgica province, which is affected by a northward (episodically strong) current regime and sediment transport. This results in mound 
structures with a different seabed appearance: the most 'active' mounds were found in the Belgica province, together with small structures that possibly could be interpreted as initial mounds. The Magellan Mounds on the other hand are clearly becoming buried, while the Hovland Mounds take an intermediate position. Partly due to their size, the latter are not buried like the Magellan Mounds, but they do not show the same abundance of live coral as the Belgica Mounds.

Overall, the Porcupine Seabight forms a unique study laboratory, containing large numbers of mounds at different stages of development, displaying both conditions of erosion and sedimentation. These different appearances and environmental regimes illustrate the importance of local current and sedimentation regimes influencing mound development.

\section{Acknowledgements}

This study used data and survey results (TOBI) acquired during a project undertaken with support of the European Union (EASSS III programme, 'Improving Human Potential', contract HPRI-CT-1999-00047) and on behalf of the Porcupine Studies Group (PSG) of the Irish Petroleum Infrastructure Programme Group 3. The PSG comprises: Agip Ireland BV, Chevron UK Ltd., Elf Petroleum Ireland BV, Enterprise Energy Ireland Ltd., Marathon International Hibernia Ltd., Philips Petroleum Company United Kingdom Ltd., Statoil Exploration (Ireland) Ltd. and the Petroleum Affairs Division of the Department of the Communication, Marine and Natural Resources.

This research is carried out in the framework of the EC-funded Fifth Framework projects GEOMOUND and ECOMOUND. Thanks to A. Freiwald for the use of the detailed bathymetry of Propeller Mound.

The authors further would like to thank the captains, crews and scientific teams of the R/V Polarstern (ANTXVII/4), the R/V L'Atalante (CARACOLE cruise) and the R/V Pelagia (cruise 197) for their support during data acquisition. D. Hebbeln and A. Kuijpers are gratefully acknowledged for their helpful comments and constructive reviews.

\section{References}

Beyer A, Schenke HW, Klenke M, Niederjasper F (2003) High resolution bathymetry of the eastern slope of the Porcupine Seabight. Mar Geol 198: 27-54

De Bergé B (2000) Epi- en endofauna geassocieerd met koudwaterkoralen in de NO Atlantische Oceaan. MSc thesis, Marine Biol Dept, Univ Gent, 133 pp

De Haas H, Grehan A, White M, shipboard scientific crew (2000) Cold-water corals in the Porcupine Bight and along the Porcupine and Rockall Bank margins, RV Pelagia cruise M2000 (64PE165). Den Helder, R Netherland Inst Sea Res (NIOZ), 25 pp

De Haas H, Huvenne V, Wheeler A, Unnithan V, shipboard scientific crew (2002) A TOBI side scan sonar survey of cold-water coral carbonate mounds in the Rockall Trough and Porcupine Sea Bight, RV Pelagia cruise M2002 (64PE197). Den Helder, R Netherland Inst Sea Res (NIOZ), 44 pp 
De Mol B (2002) Development of coral banks in Porcupine Seabight (SW Ireland). A multidisciplinary approach. PhD thesis, Fac Sci, Dept Geol Soil Sci, Univ Ghent, 363 $\mathrm{pp}$

De Mol B, Friend P, Akhmetzhanov A, Ivanov M, de Haas H, Belenkaya I, Stadnitskaya A (1999) Porcupine Seabight: short visit. In: Kenyon NH, Ivanov MK, Akhmetzhanov AM (eds) Geological processes on the Northeast Atlantic Margin, UNESCO, Paris, IOC Tech Ser 54: 34-47

De Mol B, Van Rensbergen P, Pillen S, Van Herreweghe K, Van Rooij D, McDonnell A, Huvenne V, Ivanov M, Swennen R, Henriet JP (2002) Large deep-water coral banks in the Porcupine Basin, southwest of Ireland. Mar Geol 188: 193-231

Dekindt K (2001) Contribution a l'étude de la distribution spatiale des coraux, caractérisation des differents facies et de la faune associée sur le site du Mont Thérèse. Brest, IFREMER, Dépt Environ Profond, 32 pp

Dorschel B (2003) Late Quaternary development of a deep-water carbonate mound in the northeast Atlantic. PhD thesis, Univ Bremen, $90 \mathrm{pp}$

Dorschel B, Hebbeln D, Rüggeberg A, Dullo W-Chr (submitted) Carbonate budget of a coldwater coral carbonate mound: Propeller Mound, Porcupine Seabight. Int J Earth Sci

Flood RD (1988) A lee wave model for deep-sea mudwave activity. Deep-Sea Res 35: 973 983

Foubert A (2002) Een paleomagnetische studie met zeer hoge resolutie op Calypso-kernen in Porcupine Seabight, ten zuidwesten van Ierland. MSc thesis, Dept Geol Soil Sci, Univ Gent, $151 \mathrm{pp}$

Foubert A, Beck T, Wheeler AJ, Opderbecke J, Grehan A, Klages M, Thiede J, Henriet JP, Polarstern ARK-XIX/3a Shipboard Party (2005) New view of the Belgica Mounds, Porcupine Seabight, NE Atlantic: preliminary results from the Polarstern ARK-XIX/ 3a ROV cruise. In: Freiwald A, Roberts JM (eds) Cold-water Corals and Ecosystems. Springer, Berlin Heidelberg, pp 403-415

Freiwald A (1998) Geobiology of Lophelia pertusa (Scleractinia) reefs in the North Atlantic. Habilitation thesis, Bremen Univ, $116 \mathrm{pp}$

Freiwald A, Shipboard Party (2002) RV Poseidon Cruise 292. 86 pp

Freiwald A, Dulto W-Chr, Shipboard Party (2000) RV Poseidon cruise 265, Thorshavn Galway - Kiel. $50 \mathrm{pp}$

Freiwald A, Hühnerbach V, Lindberg B, Wilson JB, Campbell J (2002) The Sula reef complex, Norwegian shelf. Facies 47: 179-200

Hall IR, McCave IN (1998) Late glacial to recent accumulation fluxes of sediments at the shelf edge and slope of NW Europe, $48-50^{\circ} \mathrm{N}$. In: Stoker MS, Evans D, Cramp A (eds) Geological processes on continental margins: sedimentation, mass-wasting and stability. Geol Soc London Spec Publ 129: 339-350

Henriet JP, De Mol B, Pillen S, Vanneste M, Van Rooij D, Versteeg W, Croker PF, Shannon PM, Unnithan V, Bouriak S, Chachkine P (1998) Gas hydrate crystals may help build reefs. Nature 391: 648-649

Henriet JP, De Mol B, Vanneste M, Huvenne V, Van Rooij D, 'Porcupine-Belgica' 97, 98 and 99 shipboard parties (2001) Carbonate mounds and slope failures in the Porcupine Basin: a development model involving fluid venting. Geol Soc London Spec Publ 188: 375-383

Hentiet JP, Guidard S, ODP "Proposal 573" Team (2002) Carbonate mounds as a possible example for microbial activity in geological processes. In: Wefer G, Billet D, Hebbeln D, Jørgensen BB, Schlüter M, van Weering T (eds) Ocean Margin Systems. Springer, Berlin Heidelberg, pp 439-455 
Hinsinger V (2002) Analyse et définition d'un module d'investigation sous-marine proche du fond. MSc thesis, Brest, Ensieta, $49 \mathrm{pp}$

Hovland M, Croker PF, Martin M (1994) Fault-associated seabed mounds (carbonate knolls?) off western Ireland and north-west Australia. Mar Petrol Geol 11: 232-246

Huthnance JM (1986) The Rockall slope current and shelf-edge processes. Proc R Soc Edinburgh 88B: 83-101

Huvenne V (2003) Spatial geophysical analysis of the Magellan carbonate build-ups and the interaction with sedimentary processes: key to a genetic interpretation? $\mathrm{PhD}$ thesis, Fac Sci, Dept Geol Soil Sci, Univ Ghent, 285 pp

Huvenne VAI, Blondel Ph, Henriet JP (2002) Textural analyses of sidescan sonar imagery from two mound provinces in the Porcupine Seabight. Mar Geol 188: 323-341

Huvenne VAI, De Mol B, Henriet JP (2003) A 3D seismic study of the morphology and spatial distribution of buried coral banks in the Porcupine Basin, SW of Ireland. Mar Geol 198: 5-25

Huvenne VAI, Bailey WR, Shannon P, Naeth J, Di Primio R, Henriet JP, Horsfield B, de Haas H, Wheeler A, Olu-Le Roy K (submitted) The Magellan mound province in the Porcupine Basin. Int J Earth Sci

Kenyon NH (1986) Evidence from bedforms for a strong poleward current along the upper continental slope of northwest Europe. Mar Geol 72: 187-198

Kenyon NH, Ivanov MK, Akhmetzhanov AM (1998) Cold-water carbonate mounds and sediment transport on the Northeast Atlantic Margin. IOC Tech Ser, Paris, UNESCO $52,178 \mathrm{pp}$

Kenyon NH, Ivanov MK, Akhmetzhanov AM (1999) Geological processes on the Northeast Atlantic Margin. IOC Tech Ser, Paris, UNESCO 54, 141 pp

Kenyon NH, Akhmetzhanov AM, Wheeler AJ, van Weering TCE, de Haas H, Ivanov MK (2003) Giant carbonate mud mounds in the Southern Rockall Trough. Mar Geol 195: $5-30$

Le Danois E (1948) Les profondeurs de la mer. Payot, Paris, 303 pp

LeBas T (2002) PRISM - Processing of Remotely-sensed Imagery for Seafloor Mapping. Version 4. Southampton, Southampton Oceanogr Cent, $196 \mathrm{pp}$

Masson DG (2001) Sedimentary processes shaping the eastern slope of the Faeroe-Shetland Channel. Cont Shelf Res 21: 825-857

Masson DG, Howe JA, Stoker MS (2002) Bottom-current sediment waves, sediment drifts and contourites in the northern Rockall Trough. Mar Geol 192: 215-237

Mohn C (2000) Über Wassermassen und Strömungen im Bereich des europäischen Kontinentalrandes westlich von Irland. PhD thesis, FB Geowiss Hamburg, Univ Hamburg, $122 \mathrm{pp}$

Mohn C, Bartsch J, Meinke J (2002) Observations of the mass and flow field at Porcupine Bank. J Mar Sci 59: 380-392

Mortensen PB, Hovland M, Brattegard T, Farestveit R (1995) Deep-water bioherms of the scleractinian coral Lophelia pertusa (L.) at $64^{\circ} \mathrm{N}$ on the Norwegian shelf: structure and associated megafauna. Sarsia 80: 145-158

Mortensen PB, Hovland MT, Fosså JH, Furevik DM (2001) Distribution, abundance and size of Lophelia pertusa coral reefs in mid-Norway in relation to seabed characteristics. J Mar Biol Ass UK 81: 581-597

Olu-Le Roy K, Caprais J-C, Crassous P, Dejonghe E, Eardley D, Freiwald A, Galeron J, Grehan A, Henriet JP, Huvenne V, Lorance P, Noel P, Opderbecke J, Pitout C, Sibuet M, Unnithan V, Vacelet J, van Weering T, Wheeler A, Zibrowius H (2002) CARACOLE cruise N/O L'Atalante \& ROV Victor. $1+2$, Brest, IFREMER 
Opderbecke J, Pitout C (2001) Cartographie acoustique et optique avec Victor. Brest, IFREMER, $27 \mathrm{pp}$

Pingree RD, Le Cann B (1989) Celtic and Armorican slope and shelf residual currents. Progr Oceanogr 23: 303-338

Pingree RD, Le Cann B (1990) Structure, strength and seasonality of the slope currents in the Bay of Biscay region. J Mar Biol Ass UK 70: 857-885

Pratje O (1924) Korallenbänke in tiefem und kühlem Wasser. Zbl Mineral Geol Paläont 1924: 410-415

Rice AL, Thurston MH, New AL (1990) Dense aggregations of a hexactinellid sponge, Pheronema carpenteri, in the Porcupine Seabight (northeast Atlantic Ocean) and possible causes. Progr Oceanogr 24: 179-196

Rice AL, Billet DSM, Thurston MH, Lampitt RS (1991) The Institute of Oceanographic Sciences biology programme in the Porcupine Seabight: background and general introduction. J Mar Biol Ass UK 71: 281-310

Rogers AD (1999) The biology of Lophelia pertusa (LINNAEUS 1758) and other deep-water reef-forming corals and impacts from human activities. Int Rev Hydrobiol 84: 315-406

Rüggeberg A, Dullo W-Chr, Dorschel B, Hebbeln D (submitted) Environmental changes and growth history of Propeller Mound, Porcupine Seabight: evidence from benthic foraminiferal assemblages. Int J Earth Sci

Schönfeld J, Zahn R (2000) Late Glacial to Holocene history of the Mediterranean Outflow. Evidence from benthic foraminiferal assemblages and stable istotopes at the Portuguese margin. Palaeogeogr Palaeoclimatol Palaeoecol 159: 85-111

Sinclair IK, Shannon PM, Williams BPJ, Harker SD, Moore JG (1994) Tectonic control on sedimentary evolution of three North Atlantic borderland Mesozoic basins. Basin Res 6: $193-218$

Stride AH (1982) Offshore tidal sands. Chapman and Hall, London, $222 \mathrm{pp}$

Swennen R, Cronin B, Ivanov M, Kozlova E, Wheeler AJ, Akhmetzhanov A, Sautkin A, Van Rooij D, Zaragosi S, Mazurenko L, Degryse C, Sumida P, Satur N, Kennedy R, Akhmanov G, Belen'kaya I, Pillen S, Naumov Y, Stadnitskaya A, De Mol B, Balashova A, Saprykina A (1998) Bottom sampling results. In: Kenyon NH, Ivanov MK, Akhmetzhanov AM (eds.) Cold-water carbonate mounds and sediment transport on the Northeast Atlantic margin. UNESCO, Paris, IOC Tech Ser 52: 59-97

Thomson CW (1873) The depths of the Sea. MacMillan, London, $527 \mathrm{pp}$

Van Rooij D, Blamart D, Unnithan V (2001) Cruise Report MD 123 - Géosciences: Leg 2, part GEOMOUND. $67 \mathrm{pp}$

Van Rooij D, De Mol B, Huvenne V, Ivanov M, Henriet JP (2003) Seismic evidence of current-controlled sedimentation in the Belgica mound province, upper Porcupine slope, southwest of Ireland. Mar Geol 195: 31-53

Van Rooij D, Blamart D, Wheeler A, Kozachenko M, Richter T, Henriet JP (submitted) Quaternary drift sediment dynamics in the Belgica mound province, Porcupine Seabight: a multidisciplinary approach. Int J Earth Sci

Wheeler A, Degryse C, Limonov A, Kenyon N (1998) The northern Porcupine Seabight. In: Kenyon NH, Ivanov MK, Akhmetzhanov AM (eds) Cold-water carbonate mounds and sediment transport on the Northeast Atlantic margin. UNESCO, Paris, IOC Tech Ser 52: $40-54$

Wheeler AJ, Bett B, Billett DSM, Masson DG, Scientific Party, Officers and Crew of RRS Discovery 248 (2000) High resolution side-scan sonar mapping of deep-water coral mounds: surface morphology and processes affecting growth. Eos, Trans, Amer Geophys Union 81: F638 
Wheeler AJ, Billet DSM, Masson DG, Grehan A (2001) The impact of demersal trawling on NE Atlantic coral ecosystems with particular reference to the northern Rockall Trough. ICES Ann Sci Conf, Oslo

Wheeler AJ, Kozachenko M, Beyer A, Foubert A, Huvenne VAI, Klages M, Masson DG, Olu-Le Roy K, Thiede J (2005) Sedimentary processes and carbonate mounds in the Belgica Mound province, Porcupine Seabight, NE Atlantic. In: Freiwald A, Roberts JM (eds) Cold-water Corals and Ecosystems. Springer, Berlin Heidelberg, pp 571-603

Wheeler AJ, Beyer A, Freiwald A, de Haas H, Huvenne VAI, Kozachenko M, Olu-Le Roy $\mathrm{K}$ (submitted). Morphology and environment of deep-water coral mounds on the NW European Margin. Int J Earth Sci

White M (2001) Hydrography and physical dynamics at the NE Atlantic margin that influence the deep-water cold coral reef ecosystem. Dept Oceanogr, NUI Galway, Ireland, $31 \mathrm{pp}$ Wynn RB, Stow DAV (2002) Classification and characterisation of deep-water sediment waves. Mar Geol 192: 7-22 